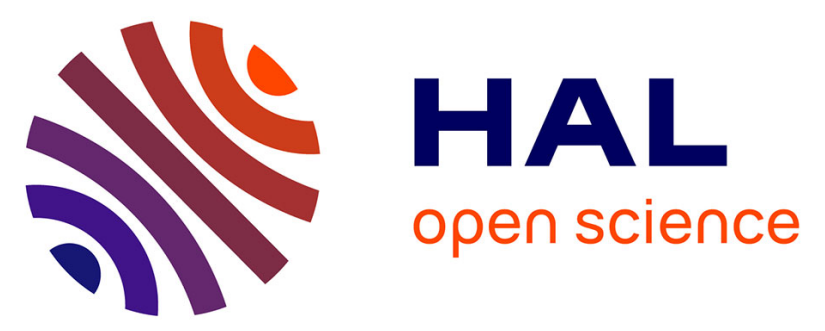

\title{
SIGNAL TRANSDUCTION IN THE HUMAN THYROCYTE AND ITS PERVERSION IN THYROID TUMORS
}

Pierre P. Roger, Wilma C.G. van Staveren, Katia Coulonval, Jacques E. Dumont, Carine Maenhaut

\section{To cite this version:}

Pierre P. Roger, Wilma C.G. van Staveren, Katia Coulonval, Jacques E. Dumont, Carine Maenhaut. SIGNAL TRANSDUCTION IN THE HUMAN THYROCYTE AND ITS PERVERSION IN THYROID TUMORS. Molecular and Cellular Endocrinology, 2010, 321 (1), pp.3. 10.1016/j.mce.2009.11.015 . hal-00582107

\section{HAL Id: hal-00582107 https://hal.science/hal-00582107}

Submitted on 1 Apr 2011

HAL is a multi-disciplinary open access archive for the deposit and dissemination of scientific research documents, whether they are published or not. The documents may come from teaching and research institutions in France or abroad, or from public or private research centers.
L'archive ouverte pluridisciplinaire HAL, est destinée au dépôt et à la diffusion de documents scientifiques de niveau recherche, publiés ou non, émanant des établissements d'enseignement et de recherche français ou étrangers, des laboratoires publics ou privés. 


\section{Accepted Manuscript}

\section{Title: SIGNAL TRANSDUCTION IN THE HUMAN THYROCYTE AND ITS PERVERSION IN THYROID TUMORS}

Authors: Pierre P. Roger, Wilma C.G. van Staveren, Katia Coulonval, Jacques E. Dumont, Carine Maenhaut

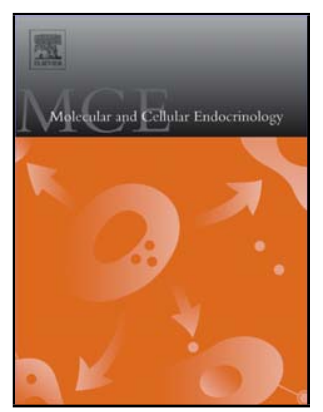

PII:

DOI:

Reference:

S0303-7207(09)00580-2 doi:10.1016/j.mce.2009.11.015

To appear in: $\quad$ Molecular and Cellular Endocrinology

Received date: $\quad$ 28-7-2009

Revised date: 23-11-2009

Accepted date: $\quad$ 27-11-2009

Please cite this article as: Roger, P.P., van Staveren, W.C.G., Coulonval, K., Dumont, J.E., Maenhaut, C., SIGNAL TRANSDUCTION IN THE HUMAN THYROCYTE AND ITS PERVERSION IN THYROID TUMORS, Molecular and Cellular Endocrinology (2008), doi:10.1016/j.mce.2009.11.015

This is a PDF file of an unedited manuscript that has been accepted for publication. As a service to our customers we are providing this early version of the manuscript. The manuscript will undergo copyediting, typesetting, and review of the resulting proof before it is published in its final form. Please note that during the production process errors may be discovered which could affect the content, and all legal disclaimers that apply to the journal pertain. 


\title{
SIGNAL TRANSDUCTION IN THE HUMAN THYROCYTE AND ITS PERVERSION IN THYROID TUMORS
}

\author{
Pierre P. Roger, Wilma C.G. van Staveren, \\ Katia Coulonval, Jacques E. Dumont*, Carine Maenhaut \\ I.R.I.B.H.M., Université Libre de Bruxelles, Campus Erasme, \\ Route de Lennik 808, B - 1070 Bruxelles.
}

*Corresponding author: J.E. Dumont, IRIBHM, ULB, School of Medicine, Campus Erasme, Bldg C, CP 602, Route de Lennik 808, B - 1070 Bruxelles.

Tel: 32255541 34, fax: 32255546 55, email : jedumont@ulb.ac.be

Keywords :

- signal transduction,

- thyroid carcinomas,

- TSH pathways,

- growth factor pathway,

- models,

- caveats.

Short title : Signal transduction in thyrocytes and tumors. 
Abstract

The study of normal signal transduction pathways regulating the proliferation and differentiation of a cell type allows to predict and to understand the perversions of these pathways which lead to tumorigenesis. In the case of the human thyroid cell, three cascades are mostly involved in tumorigenesis:

the TSH receptor-cyclic AMP cascade, the constitutive activation of which leads to autonomous adenomas and congenital hyperthyroidism.

the growth factor-Ras-MAP kinase pathway, whose constitutive activation causes follicular and papillary carcinomas.

the PI-3Kinase-PKB pathway, the activity of which is necessary for both pathways and the corresponding tumors.

The pathways and genetic events affecting them are described. Caveats in the use of models and the interpretation of results are formulated and the still pending questions are outlined. 


\section{Introduction}

Tumor cells are deviant descendants of normal cells which have gained a proliferation phenotype independent of normal physiological controls. Cancer cells have also lost, in part or totally, their differentiation status and gained a capacity to invade other tissues by migration or through the vascular or lymphatic systems. Knowing the properties of these cells is a condition for understanding their biology, and thus for proposing diagnostic signatures and therapeutic targets.

Tumors and their models

In this short review, we shall describe our knowledge of signal transduction in normal thyroid cells and show how this allowed us twenty years ago to predict how the perversion of these regulations could lead to tumors of various types and thus to anticipate the oncogenes that were discovered later (Dumont et al., 1989; Dumont et al., 1992a). The striking similitude of the conditions we defined as necessary for thyroid cell growth i.e. the necessary stimulation of both the TSH-cAMP or the EGF-MAPK pathway and of the IGF-I/insulin-PI3Kinase pathway (Roger et al., 1987; Coulonval et al., 2000; Vandeput et al., 2003) to the conditions of thyroid carcinoma induction in mice (Miller et al., 2009) illustrates a posteriori the power of this approach.

Many properties of tumor cells can be defined from the clinical evolution of the tumors and from their morphological, gene expression, epigenetic and genetic pathology. However such knowledge applies to the fully developed tumor and not necessarily to the cells which initiated and developed it. Hence the need of models to understand the development of tumors.

Various models are used to study human tumor cells, from the closer to the in vivo situation (eg tumor cells in culture or as xenotransplants in animal) to the cancer cell lines, which, through long evolution in vitro, have diverged very much from their precursors (van Staveren et al., 2009), and also to animal cell lines expressing human oncogenes. Another approach is to study the regulation of the normal cell and the mechanisms that have to be subverted in tumorigenesis.

1) Caveats on the use of data of in vivo human tumors. 
Data obtained on human tumors (e.g. gene expression) certainly represent the real tumor. However three caveats must be kept in mind :

1. The tumor, as removed, represents a given late stage in its evolution and therefore many findings (eg mutation, etc...) may be late irrelevant passenger events. The comparison of several tumors, by allowing to sort out the presumably important general common findings and thus identify a signature of anterior steps, might partially obviate this.

2. Tumors are composed of a mix of tumor cells, fibroblasts, inflammatory cells and endothelial and other vascular cell types. Tumor cells may even be the minority in the tumor. This should be taken into account in analyzing results obtained on whole tumor tissue (e.g. gene/protein expression, etc) (Delys et al., 2007).

3. The tumor cells themselves are heterogeneous, and might contain a minor population of tumor driving cells e.g. the so called cancer stem cells (CSC), the properties of which could be diluted by less competitive cells in the whole population. One might however hope that many of the properties of the driving cells will still be present in the derived cells.

All these caveats also apply to models in vivo (xenotransplants) or in vitro (direct cultures of cancer cells) of the tumors.

2) Caveats on the use of other models.

a) Primary cultures of normal human and dog thyrocytes

Human thyroid cells in primary cultures, treated with either TSH + insulin or EGF + serum + insulin, demonstrate a remarkable congruence of the patterns of gene expression in cells stimulated for one or two days, and those of autonomous adenomas and papillary carcinomas respectively (van Staveren et al., 2006; Hebrant et al., 2007). However there are important differences. For instance, while the activation of the TSH-cAMP pathway in vitro induces several negative feedbacks at transcriptional and enzyme activity levels, several of these feedbacks are not regulated or downregulated in autonomous adenomas (van Staveren et al., 2006). This suggests that tumorigenesis not only requires oncogenic events but also the suppression of negative feedbacks. This, together with the only partial congruence of results, shows that this model also has its limits. Nevertheless, investigation in human and dog 
thyroid cells has allowed to predict the tumorigenic potential of deregulated TSH-cAMP cascade, as well as the necessity of both prolonged and marked stimulation of the Raf-MAPK and the PI-3K pathway in the generation of dedifferentiated carcinomas. The in vitro studies have also shown that general regulation schemes appearing in the literature, especially in reviews, should be considered with much caution and not be interpreted literally (Dumont et al., 2001; Dumont et al., 2002).

b) Other models are even more distant from the human tumor in vivo. In vivo models of thyroid tumors in mice offer the advantages of enabling a host environment for the thyroid cells. Moreover the use of inducible tissue-specific knock-down or oncogene expression systems should allow a clearer dissection of carcinogenic pathways in vivo. However, transgenic mice expressing an oncogene in the thyroid (eg RET/PTC3) develop tumors whose morphology, gene expression and evolution are partly different from their human counterpart (Burniat et al., 2008; Jin et al., 2008).

Normal thyroid cell lines, such as the best rat cell line PC $\mathrm{Cl} 3$, differ from the rat thyroid cells in vivo and even more from human cells in vivo (Kimura et al., 2001). FRTL-5, WRT and PC Cl3 cells have been widely used to demonstrate the activity of transfected thyroid oncogenes on signaling cascades, proliferation and differentiation (see below). However the mechanistic logics of cell cycle stimulation by cAMP diverge, sometime profoundly, from the situation observed in normal human and canine thyrocytes (Kimura et al., 2001; Paternot et al., 2006b). Moreover, effects of oncogenic Ras on differentiation expression are different in human thyroid primary cultures (Gire and Wynford-Thomas, 2000; Jones et al., 2000) versus rat thyroid cell lines (Fusco et al., 1987; Avvedimento et al., 1991; Kupperman et al., 1996; De Vita et al., 2005), and, even among the latter, downstream mechanisms may vary (Cass and Meinkoth, 2000; Miller et al., 1997; Cobellis et al., 1998; Gire et al., 1999). Illegitimate coupling of tested oncogenes to downsteam effector pathways may result from their overexpression.

c) Finally human cancer cell lines retain the activated oncogenes of the cancers from which they originate, thus allowing investigation of their signaling cascades (Meireles et al., 2007; Rocha et al., 2008). However they are the result of a long Darwinian evolution in vitro. Gene expression wise, they are much more similar to each other than to the corresponding in 
vivo tumors (van Staveren et al., 2009; van Staveren et al., 2007). As a result of this evolution, under very restricted and standard conditions these cells can simplify their signal transduction and are more apt to display oncogene addiction, i.e. the reliance on one major oncogenic pathway. This may explain in part why so many successful treatments of cell lines in vitro fail on the more diversified in vivo cancers (Couto et al., 2009; van Staveren et al., 2009). On the other hand, if the activation of several pathways is needed for tumor growth, the inhibition of each one should be sufficient to impair it. Since many widely used "thyroid" cancer cell lines have been found to derive from non-thyroid cancers (Schweppe et al., 2008), researchers are urged to confirm the identity of the cell lines they are using (Ringel, 2008).

\section{Our present knowledge of signal transduction pathways controlling differentiation and proliferation in the normal dog and human thyroid cells.}

1. Caveats on the use of general signal transduction schemes as they are presented in reviews and commercial literature.

The main caveats are :

a) Most of the schemes integrate in one map data obtained in several species, organs and models. They therefore represent a catalogue of possibilities, few of which apply to any given type at all (Dumont et al., 2001). Each cell type of each species is characterized by its well defined specialized regulations. Our figures (Fig. 1A,B) are based on data obtained in dog thyroid cells in cultures; many of them have been validated in human cell cultures.

b) The schemes do not take into account kinetic and levels of activation differences. For instance in thyroid cells, both EGF and insulin/IGF-I activate both the Raf-MAPK and the PI-3K cascades. One would therefore wonder why the two signals are necessary for proliferation ! The answer is that the effect of EGF on MAPK pathway is strong and persistent (hours) while the effect on PI-3K is weak and transient. The converse is true for insulin/IGF-I. HGF which activates strongly and persistently both pathways in dog thyroid cells can act without insulin (Coulonval et al., 2000; Vandeput et al., 2003) (Fig. 2).

c) Although the physiological control of thyroid cells as well as other cells is generally similar in different species, the signal transduction mechanisms used to perform these controls vary much. For instance, while TSH activates $\mathrm{H}_{2} \mathrm{O}_{2}$ generation and thyroid hormone synthesis in all the investigated vertebrate species, it does so through the Gq-PLC 
cascade in man, the cAMP cascade in dogs, and through both in rats or mice (Massart, submitted).

d) Signal transduction has been defined in primary cultures of thyroid cells. Therefore the results apply to thyrocytes themselves but do not consider the role of the microenvironment or the interaction in thyroid with other cell types.

2. Normal controls exerted on the human thyroid cell.

Studies using primary cultures of dog and human thyrocytes have demonstrated the unique coexistence in thyroid of two distinct mitogenic modes elicited by (i) TSH acting through its receptor coupled to Gs and adenylyl cyclase activation (Fig. 1A), and (ii) growth factors (such as EGF (Roger and Dumont, 1982), FGF (Roger and Dumont, 1984) and HGF (Dremier et al., 1994) in dog cells and EGF in human thyrocytes (Errick et al., 1986)) acting through their receptor-tyrosine protein kinase pathways (Fig. 1B). TSH and cAMP induce differentiation expression, whereas growth factors and more potently EGF reversibly inhibit the expression of all differentiation markers while inducing a morphological transformation analogous to an epithelium/mesenchyme transition (EMT) (Roger and Dumont, 1984; Pohl et al., 1990; Roger et al., 1985; Coclet et al., 1991; Hebrant et al., 2007). Both TSH and EGF mitogenic stimulations are permitted or facilitated by the comitogenic activity of IGF.I (reproduced in vitro by high insulin concentrations) acting through IGF-I tyrosine kinase receptors (Roger et al., 1987; Burikhanov et al., 1996). By themselves, IGF-I and insulin only weakly stimulate proliferation (Roger et al., 1988a). In dog and human thyrocytes in primary cultures, after delayed induction of insulin receptors by TSH, physiological concentrations of insulin also permit the proliferative action of TSH (Burikhanov et al., 1996; Van Keymeulen et al., 2000a). In dog thyrocytes, in the absence of insulin/IGF-I, acetylcholine (Van Keymeulen et al., 2001) and phorbol myristate ester are also permissive for TSH-cAMP mitogenic stimulation action, presumably by the stimulation of protein kinase $\mathrm{C}$ and consequently activation of Ras (Van Keymeulen et al., 2000b), MAP kinase and increased cyclin D expression (Van Keymeulen et al., 2001). Thus the IGF-I-PI-3K pathway may complement the TSH-cAMP and the EGF-MAPK cascades by at least partially different mechanisms.

All the proliferation effects of TSH are mimicked by nonspecific modulators of the cAMP cascade, that is, cholera toxin and forskolin (which stimulate adenylyl cyclase), cAMP 
analogs (which activate the cAMP-dependent protein kinases (PKA)), and even synergistic pairs of cAMP analogues acting on the different sites of these kinases (Roger et al., 1983; Van Sande et al., 1989; Roger et al., 1988b; Dremier et al., 2007). They are reproduced in vitro and in vivo by expression of the adenosine $\mathrm{A}_{2}$ receptor, which is constitutively activated by endogenous adenosine (Maenhaut et al., 1990; Ledent et al., 1991; Ledent et al., 1992), and by constitutively active Gs $\alpha$ and cholera toxin (Zeiger et al., 1997). They are inhibited by microinjected antibodies blocking $\mathrm{G}_{\mathrm{s}}$ (Meinkoth et al., 1992). Inhibition of PKA inhibits the proliferation and differentiation effects of cAMP (Kupperman et al., 1993; Dremier et al., 1997). Moreover, stimulation of PKA by selective cAMP analogs that do not activate EPAC proteins is sufficient to fully mimic mitogenic effects of TSH and forskolin in dog thyrocytes (Dremier et al., 2007). There is, therefore, no doubt that the mitogenic and differentiating effects of TSH are mainly and probably entirely mediated by PKAs. A complementary role of the Rap1 guanyl nucleotide exchange factor EPAC and of Rap1 has been proposed in cell lines and in mice (Ribeiro-Neto et al., 2002; Hochbaum et al., 2008; Hong et al., 2008) but it is not observed in canine thyroid primary cultures (Dremier et al., 2007).

Unfortunately the role and mechanism of action of other pathways such as JAK/STAT, Wnt-FZZL, NOTCH and Sonic Hedgehog in normal human or dog thyroid cells have been little studied so far. There are indications that STATs and $\beta$ catenin (Wnt pathway) play a role in human thyroid cancers. Moreover lithium stimulates human thyrocyte proliferation by probably activating the Wnt/ $\beta$ catenin signaling (Rao et al., 2005). The fact that the higher frequency of thyroid tumors in women versus men is limited to the period between puberty and menopause (B. Jarzab, personal communication) suggests a proliferative effect of estrogens on human thyroid cells. One study thoroughly investigated the impact of sex steroids on proliferation in rat thyroid primary cultures, showing that testosterone and estradiol differentially regulate TSH-induced proliferation in cells from immature and adult rats in a gender-specific manner (Banu et al., 2001). Similar effects remain to be studied in normal human cells, nevertheless estrogen has been reported to increase proliferation in thyroid cancer cell lines (Zeng et al., 2007).

3. Biochemical aspects of the proliferative response. 
Three biochemical aspects of the proliferative response occurring at sequential times of the prereplicative phase have been considered in our characterization of mechanisms of cell cycle regulation by TSH (Fig. 1A) and growth factors (Fig. 1B).

a) Protein kinase cascades.

The pattern of protein phosphorylation induced within minutes by TSH is reproduced by forskolin and cAMP analogues. It totally diverges from the phosphorylations induced by EGF and phorbol esters (TPA) (Contor et al., 1988). EGF, HGF and phorbol ester (Roger et al., 1986) actions rapidly converge on the activation of Ras (Van Keymeulen et al., 2000b) and the resulting activation of ERK1/2 and p90 ${ }^{\mathrm{RSK}}$ (Coulonval et al., 2000; Lamy et al., 1993; Vandeput et al., 2003). PI-3-kinase and its effector enzyme PKB are activated for several hours only by insulin and IGF-I, the effect of EGF being weak and short lived (Coulonval et al., 2000). This activity is therefore the one specific feature of insulin/IGF-I action and presumably the mechanism of its facilitative effect on mitogenesis (Fig. 2). In dog thyrocytes, only HGF can trigger cell proliferation in the absence of insulin/IGF-I; this is explained by the fact that only this factor strongly activates both PI-3K and Ras-ERK cascades (Coulonval et al., 2000) (Fig. 2). By contrast, TSH and cAMP are very unique as mitogens, as they do not activate Ras, the PI-3K-PKB pathway, or any of different classes of MAP kinases in dog thyrocytes (Coulonval et al., 2000; Lamy et al., 1993; Vandeput et al., 2003; Van Keymeulen et al., 2000b)(Fig.2). TSH and cAMP also do not activate MAP kinases in human thyrocytes (Vandeput et al., 2003). The activation of the mTOR cascade (as initially indicated by $\mathrm{p} 70^{\mathrm{S} 6 \mathrm{~K}}$ phosphorylation and activation (Cass and Meinkoth, 1998; Coulonval et al., 2000)) apparently constitutes the only early convergence point of growth factor and cAMP-dependent mitogenic cascades (Blancquaert et al, submitted). A recent study has demonstrated the crucial role of this cascade for TSH-elicited thyroid follicular hyperplasia in vivo in mice (Brewer et al., 2007). Indeed, as found in dog thyroid primary cultures (Coulonval et al., 2000) and PC Cl3 cells (Blancquaert et al, submitted), TSH stimulates in mice the mTOR- $\mathrm{p} 70^{\mathrm{S} 6 \mathrm{~K}}$ axis without activating $\mathrm{PKB}$, and a rapamycin derivative abrogates the hyperplastic (but, interestingly, not the hypertrophic) responses to TSH (Brewer et al., 2007). Growth factors and IGF-I most likely activate the mTOR-raptor complex (mTORC1) through various inactivating phosphorylations of the tumor suppressor TSC2 (tuberin) (Ma and Blenis, 2009), whereas both PKB and PKA (activated by IGFI/insulin and TSH, respectively) stably activate mTORC1 by phosphorylating PRAS40 at 
Thr246 (Blancquaert et al, submitted). The cAMP-dependent mitogenesis and gene expression also appears to require the phosphorylation by PKA and activity of CREB/CREM transcription factors (Uyttersprot et al., 1999). The role of the possibly important Ral pathway downstream of Ras has been little studied. It was necessary for the transformation of human thyrocytes in vitro (Bounacer et al., 2004).

b) Induction of early mitogenic response transcription factors.

As in other types of cells, EGF and TPA first enhance c-fos and c-myc mRNA and protein levels in dog and human thyrocytes (Reuse et al., 1990; Baptist et al., 1995; Pirson et al., 1996; Heinrich and Kraiem, 1997). On the other hand, TSH and forskolin only very transiently enhance c-myc mRNA expression (Pirson et al., 1996). In fact, cAMP even decreases c-myc expression stimulated by insulin and growth factors (Reuse et al., 1990; Pirson et al., 1996). This second phenomenon is akin to what has been observed in fibroblasts, in which cAMP negatively regulates growth. As in fibroblasts, EGF and TPA enhance c-jun, and egr1 mRNA expression. However, as in fibroblasts, activators of the cAMP cascade had a minimal effect on c-fos and decreased c-jun and egr1 mRNA expression (Reuse et al., 1991; Deleu et al., 1999a; Deleu et al., 1999b; Heinrich and Kraiem, 1997; Hebrant et al., 2007).

c) Cell cycle regulatory proteins (Fig. 3).

The investigation of the pattern of proteins synthesized in response to the various proliferation stimuli has suggested very early that the proliferation of dog thyroid cells is controlled during G1 phase by at least two largely distinct, cAMP-dependent or cAMPindependent, pathways (Lamy et al., 1989). Recent microarray analyses have confirmed and extended this concept in human thyrocytes (van Staveren et al., 2006; Hebrant et al., 2007). Nevertheless, the different mitogenic cascades are expected to finally modulate the level and activity of proteins that are the common primary regulators of the cell cycle machinery. As generally considered, mitogenic signals regulate mammalian cell cycle by stimulating the accumulation of D-type cyclins and their assembly through a ill-defined mechanism with their partners, the cyclin-dependent kinases (CDK) 4 and 6. These complexes operate in mid-tolate $\mathrm{G} 1$ phase to promote progression through the restriction point, and thus commit cells to replicate their genome (Bartek et al., 1996; Sherr and Roberts, 1999; Bockstaele et al., 2006a). In the current model, this key decision depends on the initiation by cyclin D-CDK4/6 
complexes of the phosphorylation of the growth/tumor suppressor protein $\mathrm{pRb}$ (Fig. 3), which triggers the activation of transcription factors, including those of the E2F family, the synthesis of cyclin $\mathrm{E}$ and then cyclin $\mathrm{A}$, and CDK2 activation by these cyclins. Activated CDK2 in turn further phosphorylates $\mathrm{pRb}$ and other substrates and initiates and organizes the progression through the DNA synthesis phase (Sherr and Roberts, 1999). The down regulation of $\mathrm{p} 27^{\mathrm{kip} 1}$, a CDK inhibitor of the CIP/KIP family, by mitogenic factors and/or its sequestration by cyclin D-CDK complexes participate to CDK2 activation, but the proposed role of $\mathrm{p} 27^{\mathrm{kip} 1}$ and $\mathrm{p} 21^{\mathrm{cip} 1}$ as adaptors and/or nuclear anchors for cyclin D-CDK complexes suggests positive influences on cell cycle progression as well (Sherr and Roberts, 1999; Bockstaele et al., 2006a).

These mechanisms have been well studied in dog thyroid cells (Bockstaele et al., 2006a). The different mitogenic stimulations (TSH, cAMP, growth factors) require the activity of CDK4 (Lukas et al., 1996), and converge on the inactivating phosphorylation of pRb and related proteins p107 and p130 (Coulonval et al., 1997; Van Keymeulen et al., 1999), on the phosphorylation and nuclear translocation of CDK2, and on the induction of cyclin A and CDK1 (Baptist et al., 1996). These effects are dependent on insulin (Coulonval et al., 1997; Van Keymeulen et al., 1999). What is strikingly different between the cascades is the mechanism of D-type cyclin-CDK4 activation. TSH, unlike all the other known mitogenic factors, does not induce the accumulation of cyclins D, but it paradoxically stimulates the expression of $\mathrm{p} 27^{\mathrm{kip} 1}$ (Depoortere et al., 1996). However the predominant cyclin D3 is required for the proliferation stimulated by TSH, but not in the proliferation of dog thyrocytes stimulated by EGF or HGF which induce cyclins D1 and D2 (Depoortere et al., 1998; Paternot et al., 2006a). In dog thyrocytes, the formation and the nuclear translocation of essential cyclin D3-CDK4 complexes depend on the synergistic interaction of TSH and insulin. The presence of the required cyclin D3 depends on insulin/IGF-I (Van Keymeulen et al., 1999), whereas TSH stimulates the assembly of the cyclin D3-CDK4 complexes and their import into nuclei (Depoortere et al., 1998; Van Keymeulen et al., 1999) where these complexes are anchored by their association with p2 $7^{\text {kip } 1}$ (Depoortere et al., 2000; Coulonval et al., 2003). This also sequesters p27 away of CDK2 complexes (Depoortere et al., 2000), thus contributing to CDK2 activation. Moreover, cAMP exerts an additional crucial function in very late G1 phase (Roger et al., 1999; Van Keymeulen et al., 2001) to stimulate the enzymatic activity of cyclin D3-CDK4-p27 complexes, which involves the stimulation of the activating Thr172-phosphorylation of CDK4 (Bockstaele et al., 2006b; Paternot et al., 2003). 
The nature of the regulated CDK4-activating kinase complex, and whether it contains CDK7 as the catalytic subunit, remains to be defined (Bockstaele et al., 2006b; Bockstaele et al., 2006a; Bockstaele et al., 2009; Paternot et al., 2010) (Fig. 3). Importantly, TSH-stimulated CDK4 phosphorylation and activity are partly inhibited by rapamycin, indicating the involvement of the mTOR-raptor complex activated by TSH (Blancquaert et al, submitted). TGF $\beta$ selectively inhibits the cAMP-dependent proliferation of dog thyrocytes by preventing the association of the cyclin D3-CDK4 complex with nuclear $\mathrm{p} 27^{\mathrm{kip} 1}$ and the consequent activating phosphorylation of CDK4 (Depoortere et al., 2000; Coulonval et al., 2003).

The investigation of cell cycle regulatory proteins has thus clearly established that both $\mathrm{CDK} 4$ activation and $\mathrm{pRb}$ phosphorylation result from distinct but complementary actions of TSH and insulin, rather than from their interaction at an earlier step of the signalling cascades (Kimura et al., 2001; Van Keymeulen et al., 1999; Van Keymeulen et al., 2001) (Fig. 1A and 3). Together with the fact that the necessary increase of cell mass before division depends on insulin/IGF-I but not TSH (Deleu et al., 1999b), these observations provide a molecular basis for the well established physiological concept that in the regulation of normal thyroid cell proliferation, TSH is the "decisional" mitotic trigger, while locally produced IGF-I and/or circulating insulin are supporting "permissive" factors. Of note, in all these experiments, the facilitative action of insulin on TSH action but not on the EGF action can be replaced by activation of the Gq/PLC cascade by carbamylcholine (Van Keymeulen et al., 2001).

In the "dedifferentiating" proliferation mode induced by EGF and serum in dog thyrocytes, cyclin D1 and p21 $1^{\text {cip } 1}$ are transiently induced, and p21 (instead of p27 which is down regulated by growth factors) supports the nuclear translocation of cyclin D1-CDK4 complexes, whose activity also depends on regulated CDK4 phosphorylation (Depoortere et al., 1998; Paternot et al., 2006b) (Fig. 3). The main differences between the differentiationassociated mitogenic stimulation by TSH and cAMP and dedifferentiating mitogenic mode of EGF have been confirmed in human cells. Indeed, in primary cultures of normal human thyrocytes, EGF+serum increases cyclin D1 and p21 accumulation, and it stimulates the assembly and activity of cyclin D1-CDK4-p21 (Paternot et al., 2006a) (Fig. 4). By contrast, TSH (cAMP) represses cyclin D1 and p21, but stimulates the activating phosphorylation of CDK4 and the pRb-kinase activity of preexisting cyclin D3-CDK4 complexes (Paternot et al., 2006a) (Fig. 4). Cyclin D1 or cyclin D3 are thus differentially used in the distinct mitogenic 
stimulations by growth factors and $\mathrm{TSH}$, and potentially in hyperproliferative diseases generated by the overactivation of their respective signaling pathways.

\section{Negative feedback loops.}

Homeostasis in tissues implies at all levels a dynamic control with negative feedbacks. In the thyroid, the main physiological feedbacks involve the thyroid hormone inhibition of TSH synthesis in, and release by, the thyrotrophs of the pituitary and the dampening by substrate availability (i.e. iodide) of the thyroid response to TSH. These feedbacks are functional, thus do not play any role in dedifferentiated tumors. The pituitary thyroid hormone feedback does not play a role either in thyroid cells, which thanks to a constitutive activation of a protein of the TSH-cAMP cascade (TSH or Gs $\alpha$ ), are no longer dependent on TSH.

There are also negative feedback lopps within the thyrocytes themselves. Some have been well defined for the TSH-cAMP pathway and involve direct effects on enzyme activity such as the activation of cyclic AMP phosphodiesterases by phosphorylations and induction of negative effectors of the cascade such as GRK (inhibiting the receptor), RGS (inhibiting Gs), phosphodiesterases, and ICER (inhibiting the action of CREB). The conjunction of these feedback loops makes very unlikely a rapid second division of a stimulated cell. It is therefore not surprising that a suppression of some of these feedback loops is observed in autonomous adenomas which led us to suggest this is a necessary condition of tumorigenesis (van Staveren et al., 2006). The suppression of negative intracellular feedback loops in tumors resulting from other cascades, has also been observed later but not yet investigated in thyroid tumors.

\section{Proliferation and differentiation.}

Different mechanisms might contribute to explain the very different proliferation/differentiation relationship in the distinct mitogenic modes elicited by TSH and growth factors. Activation of Ras and ERK1/2, induction of c-jun, sustained expression of cmyc, induction of cyclin D1 and down regulation of $\mathrm{p} 27^{\mathrm{kip} 1}$, all have been shown to be causatively associated not only with proliferation, but also with loss of differentiation in a large variety of systems, sometimes independently of the proliferation effects. The effects of the cAMP cascade are in striking contrast with this general concept. Indeed, TSH and cAMP 
induce the proliferation of dog thyrocytes while maintaining differentiation expression; both proliferation and differentiation programs can be triggered by TSH in the same cells at the same time (Pohl et al., 1990; Pohl et al., 1993). It is tempting to relate this apparent paradox to the unique characteristics of the cAMP-dependent mitogenic pathway, such as the lack of activation (or even the inhibition) of the Ras-ERK-c-jun-cyclin D1 cascade, as demonstrated in dog and human thyrocytes. The fact that c-myc is even repressed by cAMP (after a first very transient induction) also likely prevents its dedifferentiating impact observed in a variety of cell types. The specific involvement of cyclin D3 in the cAMP-dependent mitogenic stimulation of dog and human thyrocytes is also interesting in this context (Depoortere et al., 1998; Paternot et al., 2006a). We have recently shown that the differential use of cyclin D1 or cyclin D3 affects quantitatively and qualitatively the phosphorylation site specificity of the pRb-kinase CDK4, including in dog and human thyrocytes (Paternot et al., 2006a; Paternot et al., 2006b) (Fig. 4). In addition to inhibiting E2F-dependent gene transcription related to cell cycle progression, $\mathrm{pRb}$ plays positive roles in the induction of tissue-specific gene expression by directly interacting with a variety of transcription factors, including Pax8 in thyroid cells (Miccadei et al., 2005). Whether, the selective use of cyclin D3 in the TSH cascade, associated with a more restricted pRb-kinase activity, could allow the preservation of some differentiation-related functions of $\mathrm{pRb}$ thus remains to be examined. Indeed, unlike cyclins D1 and D2, cyclin D3 is highly expressed in several quiescent tissues in vivo, and its expression is not only stimulated by mitogenic factors but also induced during several differentiation processes associated with a repression of cyclin D1 (Bartkova et al., 1998).

We now consider the distinct cAMP-dependent mitogenic pathway, which appears to be superimposed to the more general mechanisms used by growth factors, as pertaining to the specialized differentiation program of thyroid cells and some other organs (eg pituitary) (Roger et al., 1995; Lyons and Moses, 1990; Lyons et al., 1990). In dog thyrocytes, the proliferation in response to serum or growth factors specifically extincts their capacity to respond to TSH/cAMP as a mitogenic stimulus (Roger et al., 1992). Similarly, in less differentiated thyroid cancers generated by the subversion of growth factor mechanisms, the TSH-dependence of growth is generally found to be lost, and in various cell lines derived from thyroid carcinomas, cAMP and PKA activation even inhibit CDK4 activity and cell cycle progression (Rocha et al., 2008).

6. Validity of these concepts in vivo. 
The qualitative validity of these concepts in vivo has been established by using transgenic mice models. The expression in thyroid of oncogene E7 of HPV-16, which sequestrates $\mathrm{pRb}$ protein, leads to thyroid growth and (partially dedifferentiated) euthyroid goiter (Burniat et al., 2008; Coppee et al., 1996). Expression in the thyroid of the adenosine $\mathrm{A}_{2}$ receptor, which behaves as a constitutive activator of adenylyl cyclase, induces thyroid growth, goitrogenesis, and hyperthyroidism (Ledent et al., 1992). Similar, albeit weaker phenotypes are obtained in mice expressing constitutive Gs (the $\mathrm{G}$ protein activating adenylyl cyclase) (Michiels et al., 1994) or cholera toxin (Zeiger et al., 1997). A contrario, the expression in thyroid of a dominant negative CREB provokes a marked thyroid hypotrophy, suggesting the crucial role of CREB and its activating phosphorylation by PKA (Nguyen et al., 2000). By contrast, transgenic mice overexpressing both human IGF-I and IGF-I receptor in their thyroid (TgIGF-I-TgIGF-IR) develop only a mild thyroid hyperplasia and respond to a goitrogenic effect of antithyroid drugs while maintaining a comparatively low serum TSH level. This indicates some autonomy of these thyroids, as in acromegalic patients, and a much greater sensitivity to endogenous TSH (Clement et al., 2001). Recently, thyrocyte-specific deficiency of $\mathrm{Gq} / \mathrm{G}_{11}$ (the $\mathrm{G}$ proteins activating PLC $\beta$ ) in mice was shown to impair not only the TSH-stimulated iodide-organification and thyroid hormone synthesis, but also TSHdependent development of goiter (Kero et al., 2007). It remains to be defined whether this impaired follicular cell hyperplasia could result in part from a direct requirement, from the lack of induction of VEGF and angiogenesis (Kero et al., 2007) which normally accompany goitrogenesis, or from another indirect effect. Nevertheless, the phenotype of these mice suggests a role of PLC, at least permissive, in TSH-dependent goitrogenesis. PLC is activated by TSH (Van Sande et al., 2006) but even more strongly but often transiently by neurotransmitters (Raspe et al., 1986; Raspe et al., 1991). Moreover, activation of Gq/PLC by carbamycholine can facilitate cAMP-dependent mitogenesis in dog thyrocytes cultured without insulin or IGF-I (Van Keymeulen et al., 2001). Noteworthy, section of inferior laryngeal nerve in rats was similarly reported to impair both thyroid function and growth stimulated by TSH (Romeo et al., 1988). However the success of thyroid xenotransplants argues against a necessary role of neurotransmitters in vivo. On the other hand, expression of RET/PTC alone, which is a constitutive growth factor receptor, in papillary thyroid carcinoma (PTC), leads to growth and hypothyroidism and later cancer in mice (Jhiang et al., 1996; Powell et al., 1998) (see section III below). 
7. Partly different regulations in rat thyroid cell lines.

"Immortal" rat thyroid cell lines (FRTL-5, WRT and PC Cl3 cells) are well responsive to insulin/IGF-I but, when used alone, their impact on DNA-synthesis and proliferation much vary, even in different subclones of same cell line or during repeated cell passages (Kimura et al., 2001). Fibroblast growth factors stimulate proliferation while inhibiting differentiation expression in FRTL-5 and PC Cl3 cells (Logan et al., 1992; Isozaki et al., 1992; Battaglia et al., 1993). By contrast, the responsiveness to EGF of FRTL-5 and WRT cells appears a characteristic developed by "aged" cells (Kimura et al., 2001). In our hands, the proliferation of PC Cl3 cells is not affected by EGF and HGF (Kimura et al., 1999). Nevertheless these cell lines have been widely used to demonstrate/confirm the impact of thyroid oncogenes on signaling cascades, proliferation, differentiation, and transcriptomes (Saavedra et al., 2000; De Vita et al., 2000; Cobellis et al., 1998; Miyagi et al., 2004; Vitagliano et al., 2004; Cass and Meinkoth, 2000; Mesa, Jr. et al., 2006). Conditional expression (Mitsutake et al., 2005; Saavedra et al., 2000; Wang et al., 2003) or activity (De Vita et al., 2005) avoid several selection artefacts. As far as Ras-Raf-MAPK and PI3-K-PKB signal transductions are concerned, results are most often compatible with the other in vivo and in vitro models and allowed to better understand the biology of thyroid cancers. Evidence for novel potential RET/PTC effectors were obtained, such as Erk8 (Iavarone et al., 2006), Rap1 (De Falco et al., 2007), EGF receptor (Croyle et al., 2008) and $\beta$-catenin (Castellone et al., 2009).

The mechanisms of TSH/cAMP mitogenic effects have also been investigated using FRTL-5 and WRT cells (Rivas and Santisteban, 2003; Kimura et al., 2001). The capacity of TSH and cAMP to induce DNA synthesis and proliferation, either alone or in combination with insulin/IGF-I, much vary in different subclones of FRTL-5 cells, depending on variations in culture media, or even on the "aging" of this cell line in the same laboratory (Kimura et al., 2001). In different publications of the same group using WRT cells, TSH/cAMP was reported as a fully sufficient mitogen due to activation of multiple pathways (Cass et al., 1999; Tsygankova et al., 2000; Vuchak et al., 2009), or to only enhance the effect of serum (Lewis et al., 2004). Whereas the signaling cascades involved in the action of growth factors and IGF-I are likely to be well conserved in the different thyroid systems, as generally observed in the other cell types, the mechanistic logics of cell cycle regulation by cAMP has disappointingly turned out to strongly diverge in the various thyroid in vitro models (Kimura et al., 2001). These divergences do not only reflect species differences (Dumont et al., 1992b). Among the apparently similar rat thyroid cell lines, or even among different 
subclones of FRTL-5 cells, major differences have been observed (Kimura et al., 2001). For instance, the PI-3K-PKB cascade is claimed to be activated by cAMP in WRT cells (Tsygankova et al., 2001), but inhibited by cAMP in PC Cl3 cells (Lou et al., 2002). The induction of c-jun by TSH/cAMP in FRTL-5 cells and its repression by cAMP in WRT cells (Tominaga et al., 1994) as in dog (Reuse et al., 1991) and human thyrocytes (Heinrich and Kraiem, 1997) likely reflect major differences in upstream signaling cascades, and should result in divergent expression of downstream target genes, such as cyclin D1. Cyclin D1 synthesis, an accepted endpoint of mitogenic cascades, is indeed induced by cAMP in FRTL5 and $\mathrm{PC} \mathrm{Cl} 3$ cells, but rather repressed by cAMP in dog and human thyroid primary cultures (Kimura et al., 2001; Paternot et al., 2006b). Conversely TSH used alone down-regulates p27 in FRTL-5 cells (Medina et al., 1999), but not in WRT cells (Lewis et al., 2004), whereas it up-regulates it in dog and human thyrocytes (Depoortere et al., 1996; Paternot et al., 2006b).

The reasons for such discrepancies are unclear. Some signaling features, when they lead to selective proliferative advantages, might have been acquired during the establishment and continuous cultures of the cell lines and stabilized by subcloning. On the other hand, both the specific cyclin D3 requirement (Depoortere et al., 1998; Motti et al., 2003; Paternot et al., 2006a) and the cAMP-dependent, rapamycin-sensitive, regulation of CDK4 phosphorylation have been observed in both dog thyrocytes and PC Cl3 cells (Blancquaert et al, submitted). Many mechanisms demonstrated in the dog thyroid primary culture system so far apply to normal human thyrocytes, but much remains to be defined (Kimura et al., 2001; Paternot et al., 2006b).

\section{Genetic alterations commonly found in thyroid tumors.}

Different genetic alterations are involved in thyroid tumorigenesis. Their regroupment in signalling pathways illustrates the functional approach of tumorigenesis.

1. The cAMP pathway: hyperfunctioning autonomous adenomas and congenital non autoimmune hyperthyroidism (Fig. 1A)

In Europe and in Japan, one of the main mechanisms responsible for the hyperfunction and growth of thyroid autonomous adenomas is the constitutive activation of the cAMPdependent mitogenic cascade, through mutations conferring constitutive activity of the TSH receptor (50 to $80 \%)$ or an activating mutation of $\mathrm{G}_{\mathrm{s} \alpha}(8 \%)$ (Lyons et al., 1990; Parma et al., 
1993; Fuhrer et al., 1997; Russo et al., 1995; Tonacchera et al., 1999; Van Sande et al., 1995; Vanvooren et al., 2002; Hebrant et al., 2007; Ledent et al., 1991; Ledent et al., 1992; Hebrant et al., 2009). Similar mutations account for hyperfunctioning nodules in multinodular goiters (Tonacchera et al., 1999) . Autonomous adenomas are thus a well-defined example for human thyroid tissue in vivo of the predicted results of long-term stimulation by the physiological TSH receptor/cAMP dependent cascade (Dumont et al., 1989). Besides affecting thyroid cells, activating mutations in partners of the cAMP pathway also induce uncontrolled growth of other cells or tissues. Gain-of-function mutations of GNAS1, encoding $\mathrm{G}_{\mathrm{s} \alpha}$, are found in different sporadic endocrine tumors (e.g. growth hormone-secreting pituitary adenomas, Leydig cell tumors) and diverse tissues of patients with McCune-Albright syndrome, in which the mutations occur early during embryogenesis (Lania et al, 2001). Inactivating mutations in the gene encoding PKA type 1-alpha regulatory subunit (PRKAR1A), have been identified in Carney Complex, a familial multiple neoplasia syndrome (Kirschner et al, 2000). The Carney Complex has features overlapping those of the McCune-Albright syndrome, and both have thyroid pathologies as part of their phenotype. Dominant activating mutations of the TSH receptor are also the cause of familial non autoimmune hyperthyroidism (FNAH) and of sporadic congenital non autoimmune hyperthyroidism (SCNAH) (Kopp et al., 1995; Lania et al., 2001; Polak et al., 2006; Hebrant et al., 2009). In both cases, the whole gland is affected since embryogenesis, whereas in autonomous adenomas, the mutation is somatic and thus affects only one cell later in the adulthood.

In the case of autonomous adenomas, the TSH receptor mutation strongly activates the cAMP cascade in one cell which initiates the adenoma. In the case of FNAH the mutations are milder but affect all the cells. Very active mutations in all the thyroid cells would probably be lethal while mild mutations in one cell would have only a local effect. The SCNAH cases were caused by strong mutations (as in adenoma) and had to be treated energetically after birth to save the patients. We have proposed to regroup all these syndromes as one disease, genetic hyperthyroidism (Hebrant et al., 2009). Of course hyperthyroidism secondary to increased TSH secretion of pituitary origin or to thyroid stimulating antibodies (Graves disease) leads to a similar thyroid phenotype.

Animal models include transgenic mice expressing in the thyroid the adenosine $A_{2}$ receptor (Ledent et al., 1992). Constitutively active Gs (Michiels et al., 1994) or cholera toxin (Zeiger et al., 1997). Moreover thyroid tumors have been observed as a consequence of both 
conventional and conditional ablation in mice of one allele of the PRKAR1A gene, as a model of the Carney complex syndrome (Kirschner et al., 2005).

2. The Ras-MAPK pathway (Fig. 1B): Thyroid carcinomas

The distinct forms of thyroid carcinomas are characterized by different genetic alterations in signalling pathways. These genetic alterations are generally mutually exclusive.

Differentiated carcinomas (PTC, FTC) are essentially characterized by constitutive activation of the MAPK signalling pathway, resulting from mutations or rearrangements in different effectors of this pathway, essentially RET, BRAF or RAS. It should be noted that the constitutive activation of these pathways in the carcinomas is only partial but chronic contrary to the drastic effects of EGF in vitro. Animal models include transgenic mice expressing in their thyroid the RET/PTC1, RET/PTC3, and mutated B-Raf and Ras (Jhiang et al., 1996; Powell et al., 1998; Knauf et al., 2005; Santoro et al., 1996; Rochefort et al., 1996; Santelli et al., 1993). A doxycycline-inducible mouse model of thyroid targeted RET/PTC1 oncogene has been created (Knostman et al., 2007).

In addition, genetic alterations involving proteins along the PI-3K/PKB signalling pathway have been described, particularly in follicular (FTC) and anaplastic (ATC) thyroid cancers. These include genomic copy number gain and activating mutations of PIK3CA, inactivating mutations and deletions of PTEN, and RAS activating mutations (Mitsutake et al., 2006; Garcia-Rostan et al., 2005). PTEN deletion in mouse thyroid causes causes goiter and follicular adenomas (Yeager et al., 2007).

\subsection{Chromosomal rearrangements}

a) RET/PTC rearrangements

RET/PTC rearrangements have been known as one of the most common molecular alterations in thyroid cancers, especially those of the papillary type. RET encodes a membrane tyrosine kinase receptor for a family of ligands, the prototype of which is glial cellderived neurotrophic growth factor. The RET protooncogene is involved in the regulation of growth, survival, differentiation, and migration of cells of neural crest origin. The RET gene is not expressed in thyroid follicular cells but is present in parafollicular C cells. 
There are several types of RET rearrangements found in PTC, formed by the fusion of the intracellular tyrosine kinase domain of the protein with different 5 ' heterologous gene fragments which are ubiquitously expressed and possess a dimerization domain. This fusion results in the constitutive activation of the truncated tyrosine kinase portion of RET by autophosphorylation thanks to the dimerization domain of the heterologous gene. RET/PTC1 and RET/PTC3 are the most common combined forms of RET. RET/PTC1 is formed by a paracentric inversion of the long arm of chromosome 10 leading to fusion with a gene named H4/D10S170 (Grieco et al., 1990). RET/PTC3 is formed by fusion with the RFG/ELE1 gene (Minoletti et al., 1994; Santoro et al., 1994). Many other variants have been identified, mainly in children exposed to radiation after the Chernobyl power plant explosion (Ciampi et al., 2007; Alberti et al., 2003).

The prevalence of RET/PTC rearrangements varies widely among studies (8\% to $85 \%$ ) but most of them report a prevalence of $20-40 \%$ in adult sporadic PTC. The wide variability is due to different factors such as geographic variation but also the different procedures to identify the rearrangements (Zhu et al., 2006; Rhoden et al., 2006) and the genetic heterogeneity of PTC. The prevalence of RET/PTC is significantly higher in pediatric PTC (Bongarzone et al., 1996; Nikiforov et al., 1997) and in cancers from children exposed to radiation after the Chernobyl nuclear accident. In the last ones, RET/PTC was found in up to $80 \%$ of tumors removed 5-8 years after the accident and in 50-60\% of those removed 7-11 years after exposure (Ciampi and Nikiforov, 2007). Many studies have shown that short latency tumors are usually associated with the solid variant, a very aggressive form with a higher prevalence of RET/PTC3 rearrangement. By contrast, longer latency tumors are generally less aggressive, and associated with the classical variant and with the RET/PTC1 rearrangement (Unger et al., 2004; Williams et al., 2004).

b) Rearrangements involving TRK

The neurotrophic tyrosine kinase receptor (NTRK)-1 or TRK is similar in many ways to RET in that it encodes a transmembrane TK receptor for neuronal growth factor, which is normally restricted to neuronal crest-derived cells.

Similar to RET/PTC rearrangements, the 3' TK domain of TRK can be fused with the 5 ' promoter region of an ubiquitously expressed fusion gene resulting in a chimeric fusion protein with constitutively active tyrosine kinase activity. Different 5 ' fusion partners have 
been identified, including tropomyosin 3 gene (TPM3), Translocated Promotor Region gene (TPR) and TRK Fused Gene (TFG) (Alberti et al., 2003). To date, TRK rearrangements have exclusively been identified in papillary thyroid carcinomas, with a prevalence of 5-13\%.

c) The AKAP9-BRAF fusion

AKAP9-BRAF is another chromosomal rearrangement reported in about $11 \%$ of postChernobyl, radiation-associated, PTC. Only $1 \%$ of sporadic PTC display this mutation. AKAP9-BRAF results from a paracentric inversion of the long arm of the chromosome 7 and leads to the fusion of the first 8 exons of the A-kinase anchor protein 9 (AKAP9) gene with the C-terminal coding region of the BRAF protooncogene. This fusion leads to the constitutive activity of the serine-threonine kinase (Ciampi et al., 2005).

\subsection{Point mutations}

a) The B-Raf mutations

B-Raf, a member of the Raf family, encodes a cytoplasmic serine/threonine kinase, acting along the MAPK signaling pathway. Activating point mutations in the kinase region mimic phosphorylation of the protein, leading to constitutive, Ras-independent, kinase activity (Davies et al., 2002). The most common of these mutations is a T1799A missense mutation that results in a valine to glutamic acid substitution at amino acid 600 (V600E). Mutations in the B-Raf gene have been described in a variety of human neoplasms, with its highest incidence in melanoma and nevi (about 70\%) (Davies et al., 2002).

In differentiated thyroid tumors, B-Raf mutations are found in PTC, with a prevalence of about $40 \%$, which constitutes the more common molecular defect in this type of tumor (Nikiforov, 2004). Although the V600E substitution is the more frequent mutation, other, less frequent, alterations leading to constitutive B-Raf have been described : K601E substitution has been detected in the follicular variant of PTC (Trovisco et al., 2004), and small in-frame insertions or deletions around V600 have been reported (Carta et al., 2006; Hou et al., 2007a). Among PTC, B-Raf mutations appear more frequently in the classical and tall cell variants, where the prevalence of RET/PTC is usually low. BRAF mutations are also associated to older patients (Powell et al., 2005) and correlate with distant metastases and tumor aggressivity (Nikiforova et al., 2003). In addition to PTC, about $15 \%$ of poorly differentiated 
and 35\% of anaplastic carcinomas (Namba et al., 2003; Nikiforova et al., 2003) harbour the B-Raf V600E mutation.

The fact that Raf mutant induced papillary carcinomas are more dedifferentiated than carcinoma of other origin, thus take up less radioiodide and are more difficult to treat, fits in well with the very efficient dedifferentiating action of the Ras-MAPK pathway in vitro.

b) RAS mutations

Activating point mutations in codon 61 of H-Ras and N-Ras are not specific of a particular type of thyroid tumors. They are found in more than $30 \%$ of follicular adenoma and FTC (Nikiforov, 2004), but are also identified with a lower frequency in PTC (15\%), particularly in the follicular variant (Di Cristofaro et al., 2006). A subset of poorly differentiated and anaplastic carcinomas also present Ras mutations (35\% and 53\%, respectively).

3. PI-3K pathway (Fig. 1A,B)

a) PI-3KCA mutations and amplifications

The PI-3K signalling pathway is an important regulator of proliferation, apoptosis, metabolism and motility. Activating mutations in the p110 $\alpha$ catalytic subunit of PI-3K (PI3KCA) cause expression of constitutively active PI-3K proteins, resulting in PIP3 generation and activation of the downstream signalling cascade. Most of the mutations have been localized in the helicase (exon 9) and kinase (exon 20) domains of the protein (Vogt et al., 2007). In addition to activating mutations, PI-3KCA gene amplification also contributes to increased PI-3K signalling in thyroid tumors.

Among differentiated carcinomas, such alterations occur mainly in FTC (8-13\% mutation, 28\% amplification) and less frequently in PTC (2\% mutation, 12\% amplification). Their frequency in ATC increases up to $17 \%$ for PI-3KCA mutation and to $42 \%$ for gene amplification (Garcia-Rostan et al., 2005; Wang et al., 2007).

b) PTEN mutations and loss of expression 
Inactivating mutations in PTEN, a lipid and protein phosphatase counteracting the activity of PI-3K, occur with a relatively low frequency in thyroid cancer (2\% in PTC, $7 \%$ in FTC and $14 \%$ in ATC). Loss of PTEN expression following deletion in PTEN gene is more common : $3 \%$ in follicular adenoma, 22\% in PTC, 36\% in PTC and 41\% in ATC (Hou et al., 2007b; Wang et al., 2007).

In addition to these somatic mutations and deletions in PTEN, germline mutations in the PTEN gene leads to Cowden disease, a multiple hamartoma syndrome with increased susceptibility to breast, thyroid and skin tumours (Liaw et al, 1997).

4. Overexpression of growth factors and their receptors (Fig. 1B)

Quantitative or qualitative changes in the expression of local growth factors and their receptors, leading to autocrine loops and autonomous proliferation, have been often reported to be associated with thyroid carcinogenesis (Fig. 1B). They also lead to permanent activation of MAPK, PI-3K or both and their respective cascades. Examples include the overexpression of c-met/HGF receptor, sometimes in association with HGF, mainly in papillary thyroid carcinomas (Di Renzo et al., 1992; Trovato et al., 1998), of erbB/EGF receptor in association with its ligand TGF $\alpha$ (Aasland et al., 1990) and of nine genes coding for proteins involved in EGF cascade activation (Delys et al., 2007). IGF-I was also reported to be produced by thyroid adenomas at levels sufficient to obviate the requirement for exogenous insulin or IGFI in cultures derived from these tumors (Williams et al., 1988; Williams et al., 1989). In some thyroid cancers, the overexpression of insulin receptors leads to an increased formation of insulin receptor/IGF-I receptor hybrids that are activated by IGF-I (Belfiore et al., 1999). Another interesting mechanism is provided by the expression in thyroid cancers of an alternatively spliced insulin receptor isoform (insulin receptor A) which binds with high affinity IGF-II produced by the same tumor cells (Fig. 1B) (Vella et al., 2002).

5. Other pathways

a) PAX8-PPAR $\gamma$ rearrangement

PAX8-PPAR $\gamma$ rearrangement is a chromosomal translocation $\mathrm{t}(2: 3)(\mathrm{q} 13 ; \mathrm{p} 25)$ which contributes to the development of thyroid cancers (Kroll et al., 2000). PAX8 (paired-box gene 8) encodes a transcriptional factor required for the genesis of follicular cell lineages and 
regulation of thyroid-specific gene expression, whereas PPAR $\gamma$ (peroxisome proliferatoractivated receptor- $\gamma$ ) is a member of the steroid nuclear hormone receptor superfamily. The chimeric protein contains the DNA binding domain of PAX8 and functions as a dominant negative on the transcriptional activity of wild-type PPAR $\gamma$.

PAX8-PPAR $\gamma$ rearrangements are present in follicular thyroid adenoma (up to $30 \%$ ), follicular thyroid carcinomas (35\%), and in follicular variants of PTC (Castro et al., 2006; Marques et al., 2002). To date, it has not been detected in poorly differentiated and undifferentiated (anaplastic) carcinomas.

b) p53 mutations

All mutations discussed above are mainly found in differentiated thyroid cancers and are believed not to be sufficient by themselves to trigger the progression to poorly and anaplastic carcinomas. Additional alterations are required such as p53 mutations.

In thyroid tumors, p53 mutations occur in $24 \%$ and $59 \%$ of poorly differentiated and anaplastic cancers, respectively, and only in isolated cases of PTC and FTC (Nikiforov, 2004).

c) $\beta$-catenin mutations

In thyroid tumors, stabilizing mutations in $\beta$-catenin (CTNNB1), a cadherin-mediated adhesion regulator and a component of the Wnt signaling pathway, have been reported in $16 \%$ of poorly differentiated cancers and in $66 \%$ of undifferentiated carcinomas, but not in differentiated carcinomas (Garcia-Rostan et al., 1999; Nikiforov, 2004). This occurrence suggests that mutations in $\beta$-catenin play a direct role in the dedifferentiation of thyroid cancers, especially those that progress to undifferentiated carcinomas.

\section{Conclusion}

In conclusion, extensive reports suggest a constitutive activation of the MAPK signalling pathway in PTC by genetic alterations of its components. More recently, genetic abnormalities leading to constitutive activation of the PI-3K-PKB signalling pathway have been discovered, and were shown to play also an important role in thyroid tumorigenesis, 
particularly in FTC and ATC. In addition, RET/PTC or Ras are also responsible for PI-3K signalling activation in thyroid cancers, and PI-3K activation might be an essential factor for tumorigenesis (Miller et al., 2009). However, the relative importance of the PI-3K versus the MAPK signalling pathway is not fully elucidated since PI-3K activation can in turn facilitate MAPK activation (Miller et al., 2009). Additional alterations are required to go further in the dedifferentiation process. Undifferentiated anaplastic thyroid carcinomas commonly display B-Raf or Ras mutations, but no RET/PTC nor PAX8-PPAR $\gamma$ rearrangements (Nikiforov, 2004). This could be explained by the fact that B-Raf or Ras mutations may facilitate the acquisition of secondary genetic events (such as p53 and $\beta$-catenin) through induction of genomic instability (Mitsutake et al., 2006). The specific signal transduction role of PAX8PPAR $\gamma$, and the prevalence and role of the $\beta$ catenin mutations remain to be defined. p53 inactivating mutations seem to be involved in the progression rather than in the initiation of thyroid cancers.

\section{Thyroid signal transduction, oncogenes and protooncogenes.}

The parallelism between what is known of thyroid mitogenic pathways and the genetic events discovered in thyroid tumors is striking even with incomplete data: the differentiating, mitogenic cAMP pathway is involved at several steps in various forms of hyperthyroidism; the dedifferentiating mitogenic growth factor MAPK kinase pathway is involved at different levels in carcinomas. There is some evidence of the involvement of the PI-3K pathway in both differentiated and dedifferentiated tumors (Fig. 1A,B).

We had believed at one time that rather than defining the tumors by their morphology, we should classify them by their genetic origin. The results obtained so far would discourage such a classification as several different but parallel genetic events in one pathway should lead to the same phenotype.

In the case of lung cancers and glioblastomas, a systematic sequence analysis of the genome of tumors or of several hundred selected genes has shown that each individual cancer harbors about 80 different mutations with little overlap between individual cancers. Of course, among these mutations there might be many more passengers than driving mutations. However, analysis of the mutations shows that $70 \%$ of the cancers demonstrated one 
mutation in each of the two major oncogenic pathways: the Raf-MAPK pathway and the PI$3 \mathrm{~K}$ pathway and in each of the two antioncogenic pathways: the p53 and then pRb pathway (Ding et al., 2008; The Cancer Genome Atlas Research network, 2008). This clearly indicates, that, as generally admitted, carcinogenesis requires several rather than one oncogenic event. Such events could be genetic, epigenetic, or functional lysogenic like (i.e. heredity based on on/off signalling) positive feedback loops (Thomas, 1978). Thus, the oncogenic events described in section III, may be initiating but are not sufficient to elicit carcinogenesis. This is further supported by the fact that expression of one oncogene (eg RET-PTC3) in the thyroid of mice elicits thyroid growth and dedifferentiation but not general carcinomas. In fact the thyroids of such mice get, gene expression wise, more and more different from human papillary carcinomas as they age (Burniat et al., 2008). However they develop different localized, then extensive lesions... obviously as the result of further localized oncogenic event. In humans, we still have to define many of these events, even in tumors in which one oncogenic mutation has been discovered.

\section{Pending questions}

The role in thyroid carcinomas of the Ral, Wnt, NOTCH and Sonic Hedgehog and TGF $\beta$ pathways and the action of estrogens has been little studied.

The striking correlation between the in vitro delineation of mitogenic signaling pathways and the nature of the oncogenes and antioncogenes discovered in thyroid carcinomas should not lead us to believe that we understand fully what happens in the carcinomas. There are several unexplained discrepancies. Differences between observations and expectations should take into account the simplifications of our schemes of signal transduction: 1) the strength and duration of the activation, for instance the dedifferentiating action of Ras may be dose dependent (De Vita et al., 2005); 2) the existence at each step of the pathways of more or less different isoforms (eg Ras, Raf, PI-3K etc); 3) the involvement of non studied pathways Ral, JAK, STAT, Wnt/catenin, NOTCH, sonic hedgehog, estrogen, retinoic acid, T3 receptors, etc 4) the existence of unknown positive and negative feedback loops; 5) late secondary induction or repression of signalling proteins; 6) the possible role of cancer associated endothelial, inflammatory cells and fibroblasts. 
How do activating mutations of the TSHR, or Gs $\alpha$ succeed to lead to tumorigenesis without acting on the IGF-I-PI-3K pathway? Is it due to the fact that both TSH-cAMP-PKA and IGF-I-PI-3K-PKB converge on the activation of the required mTOR-raptor (mTORC1) pathway (Coulonval et al., 2000; Brewer et al., 2007)(Blancquaert et al. submitted) ? Could induction of insulin receptors making the thyrocyte sensitive to insulin (Burikhanov et al., 1996; Van Keymeulen et al., 2000a), or an insulin receptor sensitive to IGF-II (Vella et al., 2002), provide the answer?

Why does an activating mutation of B-Raf, which concerns only the MAPK cascade, lead to oncogenicity? Could induction of enzymes in other pathways (ERBB, PI-3K) explain it ?

How can different B-Raf activating mutations cause different carcinomas subtypes, BRaf V600E in classical PTCs, B-Raf K601E in PTC follicular variants ? Does this suggest different effects on pathways for the mutated proteins?

Why do mutations of Ras, which theoretically should, like RET activation, stimulate both the Raf-MAPK and PI-3K pathway, lead respectively to follicular and papillary carcinoma and not only to papillary carcinomas?

There is an apparent paradox in the fact that activating mutations of B-Raf induce a more severe form of papillary carcinoma than activation of RET which stimulates both the Raf-MAPK pathway and the PI-3K pathway (besides others such as Ral). This raises the question of the strength of the activation and of the nature of other complementary causal events. Indeed systematic sequencing of cancer genomes reveals, for each of most cancers, oncogenic events in the four major pathways: Raf-ERK, PI-3K pathway, p53 and pRb pathways (Ding et al., 2008; The Cancer Genome Atlas Research network, 2008). Moreover, even the bivalent acting RET, when expressed in the thyroid of transgenic mice, is insufficient to cause a real cancer (Burniat et al., 2008). Constitutively activated RET, in C cells, leads to a well differentiated medullary carcinoma which suggests only a mild stimulation of the RafMAPK cascade.

How do cytosolic rearranged RET-PTC link to membrane bound Ras ? Could high concentrations be the answer?

How does the level of dietary iodide influence the type of thyroid carcinoma appearing in the population? 
Finally, the recent reports of new genetic changes in subsets of carcinoma tissues (Unger et al., 2008) raise the question of the evolution of the carcinogenetic process with time and in different parts of a tumor.

\section{Conclusion}

The detailed knowledge of the normal and pathological signal transduction pathways in normal and tumor human cells is necessary for a complete understanding of the perversions which are at the basis of tumorigenesis. This knowledge in normal human thyroid cells from studies in human and other species such as dogs, led directly to the discovery of the events causing genetic hyperthyroidism. In the case of the carcinomas, although the knowledge could have led to their initiating cause, the first causing oncogene (RET/PTC) was discovered by a non a priori approach (Grieco et al., 1990).

The interpretation of the role of proposed causal events also benefits from this knowledge with some intesting diagnostic and therapeutic consequences.

The generally postulated transitions from adenoma to follicular carcinoma and from papillary and follicular to anaplastic thyroid carcinoma is supported by histological sections of human tumors. The finding of B-Raf and Ras mutations, pathognomonic of papillary, papillary and follicular carcinomas, respectively in $25 \%$ and $50 \%$ of anaplastic carcinomas (Couto et al., 2009) also supports it (Nikiforova et al., 2003). The validity of this very plausible hypothesis would certainly confer a special interest to thyroid cancers as general models but it remains to be proved.

The fact that constitutive activation of the MAPK pathway at whatever level leads to papillary carcinomas suggests that carcinomas could be diagnosed on the basis of the activation cascades rather than the initial genetic events. The phenotypic signature (eg morphologic or gene expression) is the true reflect of the pathological process involved. In some cases, eg the presence of B-Raf mutations, the genetic signature may signal the severity of the disease (Xing et al., 2009).

For the choice of treatment, among a myriad of possibilities, the knowledge of the pathways involved, could also orient the selection of probably useful agents. Moreover, knowing the level involved will allow predicting the outcome. A priori, it is no use to inhibit a pathway upstream of its constitutively active actor (eg the EGF receptor in case of a Raf 
mutation) and this has been shown to be the case in colorectal cancers (Sartore-Bianchi et al., 2009). Most of the drugs in clinical trials act on the receptors (Couto et al., 2009).

Also comprehensive knowledge could reveal metabolic steps that, although not causal, could be required for tumor development (eg angiogenesis, inflammation, etc..).

The understanding of the pathogenesis and physiopathology of carcinomas as of other diseases will result from the constant confrontation of clinical and pathological data in patients and data obtained on models, all of which have different limitations. 


\section{Acknowledgments}

The work performed in the authors'laboratories was supported by grants from the Belgian Federation against Cancer, the Communauté française de Belgique - Actions de Recherches Concertées, the Belgian Fund for Scientific Medical Research (FRSM), the National Fund for Scientific Research (FRS-FNRS, Belgium), Les Amis de l'Institut Bordet, Télévie and EU Genrisk Contract. P.P. Roger, and W.C.G. van Staveren and K. Coulonval are respectively Senior Research Associate and Scientific Research Workers of the FRS-FNRS. 


\section{References}

Aasland, R., Akslen, L.A., Varhaug, J.E., Lillehaug, J.R., 1990. Co-expression of the genes encoding transforming growth factor-alpha and its receptor in papillary carcinomas of the thyroid. Int. J. Cancer 46, 382-387.

Alberti, L., Carniti, C., Miranda, C., Roccato, E., Pierotti, M.A., 2003. RET and NTRK1 proto-oncogenes in human diseases. J. Cell Physiol 195, 168-186.

Avvedimento, V.E., Musti, A.M., Ueffing, M., Obici, S., Gallo, A., Sanchez, M., DeBrasi, D., Gottesman, M.E., 1991. Reversible inhibition of a thyroid-specific trans-acting factor by Ras. Genes Dev. 5, 22-28.

Banu, S.K., Arosh, J.A., Govindarajulu, P., Aruldhas, M.M., 2001. Testosterone and estradiol differentially regulate thyroid growth in Wistar rats from immature to adult age. Endocr. Res. 27, 447-463.

Baptist, M., Dumont, J.E., Roger, P.P., 1995. Intercellular heterogeneity of early mitogenic events: cAMP generalizes the EGF effect on c-Fos protein appearance but not on MAP kinase phosphorylation and nuclear translocation in dog thyroid epithelial cells. Exp. Cell Res. 221, $160-171$.

Baptist, M., Lamy, F., Gannon, J., Hunt, T., Dumont, J.E., Roger, P.P., 1996. Expression and subcellular localization of CDK2 and cdc2 kinases and their common partner cyclin A in thyroid epithelial cells: comparison of cyclic AMP-dependent and -independent cell cycles. J. Cell Physiol. 166, 256-273.

Bartek, J., Bartkova, J., Lukas, J., 1996. The retinoblastoma protein pathway and the restriction point. Curr. Opin. Cell Biol. 8, 805-814.

Bartkova, J., Lukas, J., Strauss, M., Bartek, J., 1998. Cyclin D3: requirement for G1/S transition and high abundance in quiescent tissues suggest a dual role in proliferation and differentiation. Oncogene 17, 1027-1037. 
Battaglia, C., Berlingieri, M.T., Martelli, M.L., Trapasso, F., Delli, B.P., Fusco, A., 1993. Mitogenic and dedifferentiating effect of the K-fgf/hst oncogene on rat thyroid PC clone 3 epithelial cells. Cell Growth Differ. 4, 185-192.

Belfiore, A., Pandini, G., Vella, V., Squatrito, S., Vigneri, R., 1999. Insulin/IGF-I hybrid receptors play a major role in IGF-I signaling in thyroid cancer. Biochimie 81, 403-407.

Bockstaele, L., Bisteau, X., Paternot, S., Roger, P.P., 2009. Differential regulation of CDK4 and CDK6, evidence that CDK4 might not be activated by CDK7, and design of a CDK6 activating mutation. Mol. Cell. Biol. 29.

Bockstaele, L., Coulonval, K., Kooken, H., Paternot, S., Roger, P.P., 2006a. Regulation of CDK4. Cell Division 1, 25.

Bockstaele, L., Kooken, H., Libert, F., Paternot, S., Dumont, J.E., de Launoit, Y., Roger, P.P., Coulonval, K., 2006b. Regulated activating Thr172 phosphorylation of cyclin-dependent kinase 4(CDK4): its relationship with cyclins and CDK "inhibitors". Mol. Cell Biol. 26, 50705085 .

Bongarzone, I., Fugazzola, L., Vigneri, P., Mariani, L., Mondellini, P., Pacini, F., Basolo, F., Pinchera, A., Pilotti, S., Pierotti, M.A., 1996. Age-related activation of the tyrosine kinase receptor protooncogenes RET and NTRK1 in papillary thyroid carcinoma. J. Clin. Endocrinol. Metab 81, 2006-2009.

Bounacer, A., McGregor, A., Skinner, J., Bond, J., Poghosyan, Z., Wynford-Thomas, D., 2004. Mutant ras-induced proliferation of human thyroid epithelial cells requires three effector pathways. Oncogene 23, 7839-7845.

Brewer, C., Yeager, N., Di Cristofano, A., 2007. Thyroid-stimulating hormone initiated proliferative signals converge in vivo on the mTOR kinase without activating AKT. Cancer Res. 67, 8002-8006.

Burikhanov, R., Coulonval, K., Pirson, I., Lamy, F., Dumont, J.E., Roger, P.P., 1996.

Thyrotropin via cyclic AMP induces insulin receptor expression and insulin co-stimulation of growth and amplifies insulin and insulin-like growth factor signaling pathways in dog thyroid epithelial cells. J. Biol. Chem. 271, 29400-29406. 
Burniat, A., Jin, L., Detours, V., Driessens, N., Goffard, J.C., Santoro, M., Rothstein, J., Dumont, J.E., Miot, F., Corvilain, B., 2008. Gene expression in RET/PTC3 and E7 transgenic mouse thyroids: RET/PTC3 but not E7 tumors are partial and transient models of human papillary thyroid cancers. Endocrinology 149, 5107-5117.

Carta, C., Moretti, S., Passeri, L., Barbi, F., Avenia, N., Cavaliere, A., Monacelli, M., Macchiarulo, A., Santeusanio, F., Tartaglia, M., Puxeddu, E., 2006. Genotyping of an Italian papillary thyroid carcinoma cohort revealed high prevalence of BRAF mutations, absence of RAS mutations and allowed the detection of a new mutation of BRAF oncoprotein (BRAF(V599lns)). Clin. Endocrinol. (Oxf) 64, 105-109.

Cass, L.A., Meinkoth, J.L., 1998. Differential effects of cyclic adenosine 3',5'-monophosphate on p70 ribosomal S6 kinase. Endocrinology 139, 1991-1998.

Cass, L.A., Meinkoth, J.L., 2000. Ras signaling through PI3K confers hormone-independent proliferation that is compatible with differentiation. Oncogene 19, 924-932.

Cass, L.A., Summers, S.A., Prendergast, G.V., Backer, J.M., Birnbaum, M.J., Meinkoth, J.L., 1999. Protein kinase A-dependent and -independent signaling pathways contribute to cyclic AMP-stimulated proliferation. Mol. Cell Biol. 19, 5882-5891.

Castellone, M.D., De, F., V, Rao, D.M., Bellelli, R., Muthu, M., Basolo, F., Fusco, A., Gutkind, J.S., Santoro, M., 2009. The beta-catenin axis integrates multiple signals downstream from RET/papillary thyroid carcinoma leading to cell proliferation. Cancer Res. 69, 1867-1876.

Castro, P., Rebocho, A.P., Soares, R.J., Magalhaes, J., Roque, L., Trovisco, V., Vieira, d.C., I, Cardoso-de-Oliveira, M., Fonseca, E., Soares, P., Sobrinho-Simoes, M., 2006. PAX8PPARgamma rearrangement is frequently detected in the follicular variant of papillary thyroid carcinoma. J. Clin. Endocrinol. Metab 91, 213-220.

Ciampi, R., Giordano, T.J., Wikenheiser-Brokamp, K., Koenig, R.J., Nikiforov, Y.E., 2007. HOOK3-RET: a novel type of RET/PTC rearrangement in papillary thyroid carcinoma. Endocr. Relat Cancer 14, 445-452. 
Ciampi, R., Knauf, J.A., Kerler, R., Gandhi, M., Zhu, Z., Nikiforova, M.N., Rabes, H.M., Fagin, J.A., Nikiforov, Y.E., 2005. Oncogenic AKAP9-BRAF fusion is a novel mechanism of MAPK pathway activation in thyroid cancer. J. Clin. Invest 115, 94-101.

Ciampi, R., Nikiforov, Y.E., 2007. RET/PTC rearrangements and BRAF mutations in thyroid tumorigenesis. Endocrinology 148, 936-941.

Clement, S., Refetoff, S., Robaye, B., Dumont, J.E., Schurmans, S., 2001. Low TSH requirement and goiter in transgenic mice overexpressing IGF-I and IGF-Ir receptor in the thyroid gland. Endocrinology 142, 5131-5139.

Cobellis, G., Missero, C., Di Lauro, R., 1998. Concomitant activation of MEK-1 and Rac-1 increases the proliferative potential of thyroid epithelial cells, without affecting their differentiation. Oncogene 17, 2047-2057.

Coclet, J., Lamy, F., Rickaert, F., Dumont, J.E., Roger, P.P., 1991. Intermediate filaments in normal thyrocytes: modulation of vimentin expression in primary cultures. Mol. Cell Endocrinol. 76, 135-148.

Contor, L., Lamy, F., Lecocq, R., Roger, P.P., Dumont, J.E., 1988. Differential protein phosphorylation in induction of thyroid cell proliferation by thyrotropin, epidermal growth factor, or phorbol ester. Mol. Cell Biol. 8, 2494-2503.

Coppee, F., Gerard, A.C., Denef, J.F., Ledent, C., Vassart, G., Dumont, J.E., Parmentier, M., 1996. Early occurrence of metastatic differentiated thyroid carcinomas in transgenic mice expressing the A2a adenosine receptor gene and the human papillomavirus type $16 \mathrm{E} 7$ oncogene. Oncogene 13, 1471-1482.

Coulonval, K., Vandeput, F., Stein, R., Kozma, S., Lamy, F., Dumont, J.E., 2000.

Phosphatidylinositol 3-kinase, protein kinase B and ribosomal S6 kinases in the stimulation of thyroid epithelial cell proliferation by cAMP and growth factors in the presence of insulin. Biochem. J. 348, 351-358.

Coulonval, K., Bockstaele, L., Paternot, S., Dumont, J.E., Roger, P.P., 2003. The cyclin D3CDK4-p27kip1 holoenzyme in thyroid epithelial cells: activation by TSH, inhibition by TGFbeta, and phosphorylations of its subunits demonstrated by two-dimensional gel electrophoresis. Exp. Cell Res. 291, 135-149. 
Coulonval, K., Maenhaut, C., Dumont, J.E., Lamy, F., 1997. Phosphorylation of the three Rb protein family members is a common step of the cAMP-, the growth factor, and the phorbol ester-mitogenic cascades but is not necessary for the hypertrophy induced by insulin. Exp. Cell Res. 233, 395-398.

Couto, J.P., Prazeres, H., Castro, P., Lima, J., Maximo, V., Soares, P., Sobrinho-Simoes, M., 2009. How molecular pathology is changing and will change the therapeutics of patients with follicular cell-derived thyroid cancer. J Clin. Pathol. 62, 414-421.

Croyle, M., Akeno, N., Knauf, J.A., Fabbro, D., Chen, X., Baumgartner, J.E., Lane, H.A., Fagin, J.A., 2008. RET/PTC-induced cell growth is mediated in part by epidermal growth factor receptor (EGFR) activation: evidence for molecular and functional interactions between RET and EGFR. Cancer Res. 68, 4183-4191.

Davies, H., Bignell, G.R., Cox, C., Stephens, P., Edkins, S., Clegg, S., Teague, J., Woffendin, H., Garnett, M.J., Bottomley, W., Davis, N., Dicks, E., Ewing, R., Floyd, Y., Gray, K., Hall, S., Hawes, R., Hughes, J., Kosmidou, V., Menzies, A., Mould, C., Parker, A., Stevens, C., Watt, S., Hooper, S., Wilson, R., Jayatilake, H., Gusterson, B.A., Cooper, C., Shipley, J., Hargrave, D., Pritchard-Jones, K., Maitland, N., Chenevix-Trench, G., Riggins, G.J., Bigner, D.D., Palmieri, G., Cossu, A., Flanagan, A., Nicholson, A., Ho, J.W., Leung, S.Y., Yuen, S.T., Weber, B.L., Seigler, H.F., Darrow, T.L., Paterson, H., Marais, R., Marshall, C.J., Wooster, R., Stratton, M.R., Futreal, P.A., 2002. Mutations of the BRAF gene in human cancer. Nature 417, 949-954.

De Falco, V., Castellone, M.D., De Vita, G., Cirafici, A.M., Hershman, J.M., Guerrero, C., Fusco, A., Melillo, R.M., Santoro, M., 2007. RET/papillary thyroid carcinoma oncogenic signaling through the Rap1 small GTPase. Cancer Res. 67, 381-390.

De Vita, G., Bauer, L., da Costa, V.M., De Felice, M., Baratta, M.G., De Menna, M., Di Lauro, R., 2005. Dose-dependent inhibition of thyroid differentiation by RAS oncogenes. Mol. Endocrinol. 19, 76-89.

De Vita, G., Berlingieri, M.T., Visconti, R., Castellone, M.D., Viglietto, G., Baldassarre, G., Zannini, M., Bellacosa, A., Tsichlis, P.N., Fusco, A., Santoro, M., 2000. Akt/protein kinase B promotes survival and hormone-independent proliferation of thyroid cells in the absence of dedifferentiating and transforming effects. Cancer Res. 60, 3916-3920. 
Deleu, S., Pirson, I., Clermont, F., Nakamura, T., Dumont, J.E., Maenhaut, C., 1999a. Immediate early gene expression in dog thyrocytes in response to growth, proliferation and differentiation stimuli. J. Cell. Physiol. 181, 342-354.

Deleu, S., Pirson, I., Coulonval, K., Drouin A., Taton, M., Clermont F, Roger, P., Nakamura T., Dumont, J.E., Maenhaut, C., 1999b. IGF-1 or insulin, and the TSH cyclic AMP cascade separately control dog and human thyroid cell growth and DNA synthesis and complement each other in inducing mitogenesis. Mol. Cell. Endocrinol. 149, 41-51.

Delys, L., Detours, V., Franc, B., Thomas, G., Bogdanova, T., Tronko, M., Libert, F., Dumont, J.E., Maenhaut, C., 2007. Gene expression and the biological phenotype of papillary thyroid carcinomas. Oncogene 26, 7894-7903.

Depoortere, F., Dumont, J.E., Roger, P.P., 1996. Paradoxical accumulation of the cyclindependent kinase inhibitor p27kip1 during the cAMP-dependent mitogenic stimulation of thyroid epithelial cells. J. Cell Sci. 109, 1759-1764.

Depoortere, F., Pirson, I., Bartek, J., Dumont, J.E., Roger, P.P., 2000. Transforming growth factor beta(1) selectively inhibits the cyclic AMP-dependent proliferation of primary thyroid epithelial cells by preventing the association of cyclin D3-cdk4 with nuclear p27(kip1). Mol. Biol. Cell 11, 1061-1076.

Depoortere, F., Van Keymeulen, A., Lukas, J., Costagliola, S., Bartkova, J., Dumont, J.E., Bartek, J., Roger, P.P., Dremier, S., 1998. A requirement for cyclin D3-cyclin-dependent kinase (cdk)-4 assembly in the cyclic adenosine monophosphate-dependent proliferation of thyrocytes. J. Cell Biol. 140, 1427-1439.

Di Cristofaro, J., Marcy, M., Vasko, V., Sebag, F., Fakhry, N., Wynford-Thomas, D., De Micco, C., 2006. Molecular genetic study comparing follicular variant versus classic papillary thyroid carcinomas: association of N-ras mutation in codon 61 with follicular variant. Hum. Pathol. 37, 824-830.

Di Renzo, M.F., Olivero, M., Ferro, S., Prat, M., Bongarzone, I., Pilotti, S., Belfiore, A., Costantino, A., Vigneri, R., Pierotti, M.A., 1992. Overexpression of the c-MET/HGF receptor gene in human thyroid carcinomas. Oncogene 7, 2549-2553. 
Ding, L., Getz, G., Wheeler, D.A., Mardis, E.R., McLellan, M.D., Cibulskis, K., Sougnez, C., Greulich, H., Muzny, D.M., Morgan, M.B., Fulton, L., Fulton, R.S., Zhang, Q., Wendl, M.C., Lawrence, M.S., Larson, D.E., Chen, K., Dooling, D.J., Sabo, A., Hawes, A.C., Shen, H., Jhangiani, S.N., Lewis, L.R., Hall, O., Zhu, Y., Mathew, T., Ren, Y., Yao, J., Scherer, S.E., Clerc, K., Metcalf, G.A., Ng, B., Milosavljevic, A., Gonzalez-Garay, M.L., Osborne, J.R., Meyer, R., Shi, X., Tang, Y., Koboldt, D.C., Lin, L., Abbott, R., Miner, T.L., Pohl, C., Fewell, G., Haipek, C., Schmidt, H., Dunford-Shore, B.H., Kraja, A., Crosby, S.D., Sawyer, C.S., Vickery, T., Sander, S., Robinson, J., Winckler, W., Baldwin, J., Chirieac, L.R., Dutt, A., Fennell, T., Hanna, M., Johnson, B.E., Onofrio, R.C., Thomas, R.K., Tonon, G., Weir, B.A., Zhao, X., Ziaugra, L., Zody, M.C., Giordano, T., Orringer, M.B., Roth, J.A., Spitz, M.R., Wistuba, I.I., Ozenberger, B., Good, P.J., Chang, A.C., Beer, D.G., Watson, M.A., Ladanyi, M., Broderick, S., Yoshizawa, A., Travis, W.D., Pao, W., Province, M.A., Weinstock, G.M., Varmus, H.E., Gabriel, S.B., Lander, E.S., Gibbs, R.A., Meyerson, M., Wilson, R.K., 2008. Somatic mutations affect key pathways in lung adenocarcinoma. Nature $455,1069-1075$.

Dremier, S., Milenkovic, M., Blancquaert, S., Dumont, J.E., Doskeland, S.O., Maenhaut, C., Roger, P.P., 2007. Cyclic adenosine 3',5'-monophosphate (cAMP)-dependent protein kinases, but not exchange proteins directly activated by cAMP (Epac), mediate thyrotropin/cAMPdependent regulation of thyroid cells. Endocrinology 148, 4612-4622.

Dremier, S., Pohl, V., Poteet-Smith, C., Roger, P.P., Corbin, J., Doskeland, S.O., Dumont, J.E., Maenhaut, C., 1997. Activation of cyclic AMP-dependent kinase is required but may not be sufficient to mimic cyclic AMP-dependent DNA synthesis and thyroglobulin expression in dog thyroid cells. Mol. Cell. Biol. 17, 6717-6726.

Dremier, S., Taton, M., Coulonval, K., Nakamura, T., Matsumoto, K., Dumont, J.E., 1994. Mitogenic, dedifferentiating, and scattering effects of hepatocyte growth factor on dog thyroid cells. Endocrinology 135, 135-140.

Dumont, J.E., Dremier, S., Pirson, I., Maenhaut, C., 2002. Cross signaling, cell specificity, and physiology. Am. J Physiol Cell Physiol 283, C2-28.

Dumont, J.E., Jauniaux, J.C., Roger, P.P., 1989. The cyclic AMP-mediated stimulation of cell proliferation. Trends. Biochem. Sci. 14, 67-71. 
Dumont, J.E., Lamy, F., Roger, P., Maenhaut, C., 1992a. Physiological and pathological regulation of thyroid cell proliferation and differentiation by thyrotropin and other factors. Physiol. Rev. 72, 667-697.

Dumont, J.E., Lamy, F., Roger, P., Maenhaut, C., 1992b. Physiological and pathological regulation of thyroid cell proliferation and differentiation by thyrotropin and other factors. Physiol. Rev. 72, 667-697.

Dumont, J.E., Pecasse, F., Maenhaut, C., 2001. Crosstalk and specificity in signalling. Are we crosstalking ourselves into general confusion? Cell Signal. 13, 457-463.

Errick, J.E., Ing, K.W., Eggo, M.C., Burrow, G.N., 1986. Growth and differentiation in cultured human thyroid cells: effects of epidermal growth factor and thyrotropin. In Vitro Cell Dev. Biol. 22, 28-36.

Fuhrer, D., Wonerow, P., Willgerodt, H., Paschke, R., 1997. Identification of a new thyrotropin receptor germline mutation (Leu629Phe) in a family with neonatal onset of autosomal dominant nonautoimmune hyperthyroidism. J. Clin. Endocrinol. Metab 82, 42344238.

Fusco, A., Berlingieri, M.T., Di-Fiore, P.P., Portella, G., Grieco, M., Vecchio, G., 1987. Oneand two-step transformations of rat thyroid epithelial cells by retroviral oncogenes. Mol. Cell Biol. 7, 3365-3370.

Garcia-Rostan, G., Costa, A.M., Pereira-Castro, I., Salvatore, G., Hernandez, R., Hermsem, M.J., Herrero, A., Fusco, A., Cameselle-Teijeiro, J., Santoro, M., 2005. Mutation of the PIK3CA gene in anaplastic thyroid cancer. Cancer Res. 65, 10199-10207.

Garcia-Rostan, G., Tallini, G., Herrero, A., D'Aquila, T.G., Carcangiu, M.L., Rimm, D.L., 1999. Frequent mutation and nuclear localization of beta-catenin in anaplastic thyroid carcinoma. Cancer Res. 59, 1811-1815.

Gire, V., Marshall, C.J., Wynford-Thomas, D., 1999. Activation of mitogen-activated protein kinase is necessary but not sufficient for proliferation of human thyroid epithelial cells induced by mutant Ras. Oncogene 18, 4819-4832. 
Gire, V., Wynford-Thomas, D., 2000. RAS oncogene activation induces proliferation in normal human thyroid epithelial cells without loss of differentiation. Oncogene 19, 737-744.

Grieco, M., Santoro, M., Berlingieri, M.T., Melillo, R.M., Donghi, R., Bongarzone, I., Pierotti, M.A., Della, P.G., Fusco, A., Vecchio, G., 1990. PTC is a novel rearranged form of the ret proto-oncogene and is frequently detected in vivo in human thyroid papillary carcinomas. Cell 60, 557-563.

Hebrant, A., Van Sande, J., Roger, P.P., Patey, M., Klein, M., Bournaud, C., Savagner, F., Leclere, J., Dumont, J.E., van Staveren, W.C., Maenhaut, C., 2009. Thyroid gene expression in familial nonautoimmune hyperthyroidism shows common characteristics with hyperfunctioning autonomous adenomas. J Clin. Endocrinol. Metab 94, 2602-2609.

Hebrant, A., van Staveren, W.C., Delys, L., Solis, D.W., Bogdanova, T., Andry, G., Roger, P., Dumont, J.E., Libert, F., Maenhaut, C., 2007. Long-term EGF/serum-treated human thyrocytes mimic papillary thyroid carcinomas with regard to gene expression. Exp. Cell Res. 313, 3276-3284.

Heinrich, R., Kraiem, Z., 1997. The protein kinase A pathway inhibits c-jun and c-fos protooncogene expression induced by the protein kinase $\mathrm{C}$ and tyrosine kinase pathways in cultured human thyroid follicles. J. Clin. Endocrinol. Metab. 82, 1839-1844.

Hochbaum, D., Hong, K., Barila, G., Ribeiro-Neto, F., Altschuler, D.L., 2008. Epac, in synergy with cAMP-dependent protein kinase (PKA), is required for cAMP-mediated mitogenesis. J Biol. Chem. 283, 4464-4468.

Hong, K., Lou, L., Gupta, S., Ribeiro-Neto, F., Altschuler, D.L., 2008. A novel Epac-RapPP2A signaling module controls cAMP-dependent Akt regulation. J Biol. Chem. 283, 2312923138.

Hou, P., Liu, D., Shan, Y., Hu, S., Studeman, K., Condouris, S., Wang, Y., Trink, A., El Naggar, A.K., Tallini, G., Vasko, V., Xing, M., 2007a. Genetic alterations and their relationship in the phosphatidylinositol 3-kinase/Akt pathway in thyroid cancer. Clin. Cancer Res. 13, 1161-1170.

Hou, P., Liu, D., Xing, M., 2007b. Functional characterization of the T1799-1801del and A1799-1816ins BRAF mutations in papillary thyroid cancer. Cell Cycle 6, 377-379. 
Iavarone, C., Acunzo, M., Carlomagno, F., Catania, A., Melillo, R.M., Carlomagno, S.M., Santoro, M., Chiariello, M., 2006. Activation of the Erk8 mitogen-activated protein (MAP) kinase by RET/PTC3, a constitutively active form of the RET proto-oncogene. J Biol. Chem. 281, 10567-10576.

Isozaki, O., Emoto, N., Tsushima, T., Sato, Y., Shizume, K., Demura, H., Akamizu, T., Kohn, L.D., 1992. Opposite regulation of deoxyribonucleic acid synthesis and iodide uptake in rat thyroid cells by basic fibroblast growth factor: correlation with opposite regulation of c-fos and thyrotropin receptor gene expression. Endocrinology 131, 2723-2732.

Jhiang, S.M., Sagartz, J.E., Tong, Q., Parker-Thornburg, J., Capen, C.C., Cho, J.Y., Xing, S., Ledent, C., 1996. Targeted expression of the ret/PTC1 oncogene induces papillary thyroid carcinomas. Endocrinology 137, 375-378.

Jin, L., Burniat, A., Dumont, J.E., Miot, F., Corvilain, B., Franc, B., 2008. Human thyroid tumours, the puzzling lessons from E7 and RET/PTC3 transgenic mice. Br. J. Cancer 99, 1874-1883.

Jones, C.J., Kipling, D., Morris, M., Hepburn, P., Skinner, J., Bounacer, A., Wyllie, F.S., Ivan, M., Bartek, J., Wynford-Thomas, D., Bond, J.A., 2000. Evidence for a telomereindependent "clock" limiting RAS oncogene-driven proliferation of human thyroid epithelial cells. Mol. Cell Biol. 20, 5690-5699.

Kero, J., Ahmed, K., Wettschureck, N., Tunaru, S., Wintermantel, T., Greiner, E., Schutz, G., Offermanns, S., 2007. Thyrocyte-specific Gq/G11 deficiency impairs thyroid function and prevents goiter development. J Clin. Invest 117, 2399-2407.

Kimura, T., Dumont, J.E., Fusco, A., Golstein, J., 1999. Insulin and TSH promote growth in size of $\mathrm{PC} \mathrm{Cl3}$ rat thyroid cells, possibly via a pathway different from DNA synthesis: comparison with FRTL-5 cells. Eur. J. Endocrinol. 140, 94-103.

Kimura, T., Van Keymeulen, A., Golstein, J., Fusco, A., Dumont, J.E., Roger, P.P., 2001. Regulation of thyroid cell proliferation by thyrotropin and other factors : a critical evaluation of in vitro models. Endocr. Rev. 22, 631-656. 
Kirschner, L.S., Kusewitt, D.F., Matyakhina, L., Towns, W.H., Carney, J.A., Westphal, H., Stratakis, C.A., 2005. A mouse model for the Carney complex tumor syndrome develops neoplasia in cyclic AMP-responsive tissues. Cancer Res. 65, 4506-4514.

Knauf, J.A., Ma, X., Smith, E.P., Zhang, L., Mitsutake, N., Liao, X.H., Refetoff, S.,

Nikiforov, Y.E., Fagin, J.A., 2005. Targeted expression of BRAFV600E in thyroid cells of transgenic mice results in papillary thyroid cancers that undergo dedifferentiation. Cancer Res. 65, 4238-4245.

Knostman, K.A., Venkateswaran, A., Zimmerman, B., Capen, C.C., Jhiang, S.M., 2007. Creation and characterization of a doxycycline-inducible mouse model of thyroid-targeted RET/PTC1 oncogene and luciferase reporter gene coexpression. Thyroid 17, 1181-1188.

Kopp, P., Van Sande, J., Parma, J., Duprez, L., Gerber, H., Joss, E., Jameson, J.L., Dumont, J.E., Vassart, G., 1995. Brief report: congenital hyperthyroidism caused by a mutation in the thyrotropin-receptor gene. N. Engl. J. Med. 332, 150-154.

Kroll, T.G., Sarraf, P., Pecciarini, L., Chen, C.J., Mueller, E., Spiegelman, B.M., Fletcher, J.A., 2000. PAX8-PPARgamma1 fusion oncogene in human thyroid carcinoma [corrected]. Science 289, 1357-1360.

Kupperman, E., Wen, W., Meinkoth, J.L., 1993. Inhibition of thyrotropin-stimulated DNA synthesis by microinjection of inhibitors of cellular Ras and cyclic AMP-dependent protein kinase. Mol. Cell Biol. 13, 4477-4484.

Kupperman, E., Wofford, D., Wen, W., Meinkoth, J.L., 1996. Ras inhibits thyroglobulin expression but not cyclic adenosine monophosphate-mediated signaling in Wistar rat thyrocytes. Endocrinology 137, 96-104.

Lamy, F., Roger, P., Lecocq, R., Dumont, J.E., 1989. Protein synthesis during induction of DNA replication in thyroid epithelial cells: evidence for late markers of distinct mitogenic pathways. J. Cell Physiol. 138, 568-578.

Lamy, F., Wilkin, F., Baptist, M., Posada, J., Roger, P.P., Dumont, J.E., 1993.

Phosphorylation of mitogen-activated protein kinases is involved in the epidermal growth factor and phorbol ester, but not in the thyrotropin/cAMP, thyroid mitogenic pathway. J. Biol. Chem. 268, 8398-8401. 
Lania, A., Mantovani, G., Spada, A., 2001. G protein mutations in endocrine diseases. Eur. J. Endocrinol. 145, 543-559.

Ledent, C., Dumont, J.E., Vassart, G., Parmentier, M., 1992. Thyroid expression of an A2 adenosine receptor transgene induces thyroid hyperplasia and hyperthyroidism. EMBO J. 11, 537-542.

Ledent, C., Parmentier, M., Maenhaut, C., Taton, M., Pirson, I., Lamy, F., Roger, P., Dumont, J.E., 1991. The TSH cyclic AMP cascade in the control of thyroid cell proliferation: the story of a concept. Thyroidology. 3, 97-101.

Lewis, A.E., Fikaris, A.J., Prendergast, G.V., Meinkoth, J.L., 2004. Thyrotropin and serum regulate thyroid cell proliferation through differential effects on p27 expression and localization. Mol. Endocrinol. 18, 2321-2332.

Logan, A., Black, E.G., Gonzalez, A.M., Buscaglia, M., Sheppard, M.C., 1992. Basic fibroblast growth factor: an autocrine mitogen of rat thyroid follicular cells? Endocrinology $130,2363-2372$.

Lou, L., Urbani, J., Ribeiro-Neto, F., Altschuler, D.L., 2002. cAMP inhibition of Akt is mediated by activated and phosphorylated Rap1b. J Biol. Chem. 277, 32799-32806.

Lukas, J., Bartkova, J., Bartek, J., 1996. Convergence of mitogenic signalling cascades from diverse classes of receptors at the cyclin D-cyclin-dependent kinase-pRb- controlled G1 checkpoint. Mol. Cell. Biol. 16, 6917-6925.

Lyons, J., Landis, C.A., Harsh, G., Vallar, L., Grunewald, K., Feichtinger, H., Duh, Q.Y., Clark, O.H., Kawasaki, E., Bourne, H.R., 1990. Two G protein oncogenes in human endocrine tumors. Science 249, 655-659.

Lyons, R.M., Moses, H.L., 1990. Transforming growth factors and the regulation of cell proliferation. Eur. J. Biochem. 187, 467-473.

Ma, X.M., Blenis, J., 2009. Molecular mechanisms of mTOR-mediated translational control. Nat. Rev. Mol. Cell Biol. 10, 307-318.

Maenhaut, C., Van Sande, J., Libert, F., Abramowicz, M., Parmentier, M., Vanderhaegen, J.J., Dumont, J.E., Vassart, G., Schiffmann, S., 1990. RDC8 codes for an adenosine A2 
receptor with physiological constitutive activity. Biochem. Biophys. Res. Commun. 173, 1169-1178.

Marques, A.R., Espadinha, C., Catarino, A.L., Moniz, S., Pereira, T., Sobrinho, L.G., Leite, V., 2002. Expression of PAX8-PPAR gamma 1 rearrangements in both follicular thyroid carcinomas and adenomas. J. Clin. Endocrinol. Metab 87, 3947-3952.

Medina, D.L., Velasco, J.A., Santisteban, P., 1999. Somatostatin is expressed in FRTL-5 thyroid cells and prevents thyrotropin-mediated down-regulation of the cyclin-dependent kinase inhibitor p27kip1. Endocrinology 140, 87-95.

Meinkoth, J.L., Goldsmith, P.K., Spiegel, A.M., Feramisco, J.R., Burrow, G.N., 1992. Inhibition of thyrotropin-induced DNA synthesis in thyroid follicular cells by microinjection of an antibody to the stimulatory $\mathrm{G}$ protein of adenylate cyclase, Gs. J. Biol. Chem. 267, 13239-13245.

Meireles, A.M., Preto, A., Rocha, A.S., Rebocho, A.P., Maximo, V., Pereira-Castro, I., Moreira, S., Feijao, T., Botelho, T., Marques, R., Trovisco, V., Cirnes, L., Alves, C., Velho, S., Soares, P., Sobrinho-Simoes, M., 2007. Molecular and genotypic characterization of human thyroid follicular cell carcinoma-derived cell lines. Thyroid 17, 707-715.

Mesa, C., Jr., Mirza, M., Mitsutake, N., Sartor, M., Medvedovic, M., Tomlinson, C., Knauf, J.A., Weber, G.F., Fagin, J.A., 2006. Conditional activation of RET/PTC3 and BRAFV600E in thyroid cells is associated with gene expression profiles that predict a preferential role of BRAF in extracellular matrix remodeling. Cancer Res. 66, 6521-6529.

Miccadei, S., Provenzano, C., Mojzisek, M., Giorgio, N.P., Civitareale, D., 2005.

Retinoblastoma protein acts as Pax 8 transcriptional coactivator. Oncogene 24, 6993-7001.

Michiels, F.M., Caillou, B., Talbot, M., Dessarps-Freichey, F., Maunoury, M.T., Schlumberger, M., Mercken, L., Monier, R., Feunteun, J., 1994. Oncogenic potential of guanine nucleotide stimulatory factor alpha subunit in thyroid glands of transgenic mice. Proc. Natl. Acad. Sci. U. S. A. 91, 10488-10492.

Miller, K.A., Yeager, N., Baker, K., Liao, X.H., Refetoff, S., Di Cristofano, A., 2009. Oncogenic Kras requires simultaneous PI3K signaling to induce ERK activation and transform thyroid epithelial cells in vivo. Cancer Res. 69, 3689-3694. 
Miller, M.J., Prigent, S., Kupperman, E., Rioux, L., Park, S.H., Feramisco, J.R., White, M.A., Rutkowski, J.L., Meinkoth, J.L., 1997. RalGDS functions in Ras- and cAMP-mediated growth stimulation. J. Biol. Chem. 272, 5600-5605.

Minoletti, F., Butti, M.G., Coronelli, S., Miozzo, M., Sozzi, G., Pilotti, S., Tunnacliffe, A., Pierotti, M.A., Bongarzone, I., 1994. The two genes generating RET/PTC3 are localized in chromosomal band 10q11.2. Genes Chromosomes. Cancer 11, 51-57.

Mitsutake, N., Knauf, J.A., Mitsutake, S., Mesa, C., Jr., Zhang, L., Fagin, J.A., 2005. Conditional BRAFV600E expression induces DNA synthesis, apoptosis, dedifferentiation, and chromosomal instability in thyroid PCCL3 cells. Cancer Res. 65, 2465-2473.

Mitsutake, N., Miyagishi, M., Mitsutake, S., Akeno, N., Mesa, J.C., Knauf, J.A., Zhang, L., Taira, K., Fagin, J.A., 2006. BRAF mediates RET/PTC-induced MAPK activation in thyroid cells: functional support for requirement of the RET/PTC-RAS-BRAF pathway in papillary thyroid carcinogenesis. Endocrinology 147, 1014-1019.

Miyagi, E., Braga-Basaria, M., Hardy, E., Vasko, V., Burman, K.D., Jhiang, S., Saji, M., Ringel, M.D., 2004. Chronic expression of RET/PTC 3 enhances basal and insulin-stimulated PI3 kinase/AKT signaling and increases IRS-2 expression in FRTL-5 thyroid cells. Mol. Carcinog. 41, 98-107.

Motti, M.L., Boccia, A., Belletti, B., Bruni, P., Troncone, G., Cito, L., Monaco, M., Chiappetta, G., Baldassarre, G., Palombini, L., Fusco, A., Viglietto, G., 2003. Critical role of cyclin D3 in TSH-dependent growth of thyrocytes and in hyperproliferative diseases of the thyroid gland. Oncogene 22, 7576-7586.

Namba, H., Nakashima, M., Hayashi, T., Hayashida, N., Maeda, S., Rogounovitch, T.I., Ohtsuru, A., Saenko, V.A., Kanematsu, T., Yamashita, S., 2003. Clinical implication of hot spot BRAF mutation, V599E, in papillary thyroid cancers. J. Clin. Endocrinol. Metab 88, 4393-4397.

Nguyen, L.Q., Kopp, P., Martinson, F., Stanfield, K., Roth, S.I., Jameson, J.L., 2000. A dominant negative CREB (cAMP response element-binding protein) isoform inhibits thyrocyte growth, thyroid-specific gene expression, differentiation, and function. Mol. Endocrinol. 14, 1448-1461. 
Nikiforov, Y.E., 2004. Genetic alterations involved in the transition from well-differentiated to poorly differentiated and anaplastic thyroid carcinomas. Endocr. Pathol. 15, 319-327.

Nikiforov, Y.E., Rowland, J.M., Bove, K.E., Monforte-Munoz, H., Fagin, J.A., 1997. Distinct pattern of ret oncogene rearrangements in morphological variants of radiation-induced and sporadic thyroid papillary carcinomas in children. Cancer Res. 57, 1690-1694.

Nikiforova, M.N., Kimura, E.T., Gandhi, M., Biddinger, P.W., Knauf, J.A., Basolo, F., Zhu, Z., Giannini, R., Salvatore, G., Fusco, A., Santoro, M., Fagin, J.A., Nikiforov, Y.E., 2003. BRAF mutations in thyroid tumors are restricted to papillary carcinomas and anaplastic or poorly differentiated carcinomas arising from papillary carcinomas. J. Clin. Endocrinol. Metab 88, 5399-5404.

Parma, J., Duprez, L., Van Sande, J., Cochaux, P., Gervy, C., Mockel, J., Dumont, J., Vassart, G., 1993. Somatic mutations in the thyrotropin receptor gene cause hyperfunctioning thyroid adenomas. Nature 365, 649-651.

Paternot, S., Arsenijevic, T., Coulonval, K., Bockstaele, L., Dumont, J.E., Roger, P.P., 2006a. Distinct Specificities of pRb Phosphorylation by CDK4 Activated by Cyclin D1 or Cyclin D3: Differential Involvement in the Distinct Mitogenic Modes of Thyroid Epithelial Cells. Cell Cycle 5, 61-70.

Paternot, S., Bockstaele, L., Bisteau, X., Kooken, H., Coulonval, K., Roger, P.P., 2010. Rb inactivation in cell cycle and cancer : The puzzle of highly regulated activating phosphorylation of CDK4 versus constitutively active CDK-activating kinase. Cell Cycle 9, in press.

Paternot, S., Coulonval, K., Dumont, J.E., Roger, P.P., 2003. Cyclic AMP-dependent phosphorylation of cyclin D3-bound CDK4 determines the passage through the cell cycle restriction point in thyroid epithelial cells. J. Biol. Chem. 278, 26533-26540.

Paternot, S., Dumont, J.E., Roger, P.P., 2006b. Differential utilization of cyclin D1 and cyclin D3 in the distinct mitogenic stimulations of human thyrocytes by growth factors and TSH. Mol. Endocrinol. 20, 3279-3292.

Pirson, I., Coulonval, K., Lamy, F., Dumont, J.E., 1996. c-Myc expression is controlled by the mitogenic cAMP-cascade in thyrocytes. J. Cell Physiol. 168, 59-70. 
Pohl, V., Abramowicz, M., Vassart, G., Dumont, J.E., Roger, P.P., 1993. Thyroperoxidase mRNA in quiescent and proliferating thyroid epithelial cells: expression and subcellular localization studied by in situ hybridization. Eur. J. Cell Biol. 62, 94-104.

Pohl, V., Roger, P.P., Christophe, D., Pattyn, G., Vassart, G., Dumont, J.E., 1990.

Differentiation expression during proliferative activity induced through different pathways: in situ hybridization study of thyroglobulin gene expression in thyroid epithelial cells. J. Cell Biol. 111, 663-672.

Polak, M., Legac, I., Vuillard, E., Guibourdenche, J., Castanet, M., Luton, D., 2006.

Congenital hyperthyroidism: the fetus as a patient. Horm. Res. 65, 235-242.

Powell, D.J., Russell, J., Nibu, K., Li, G., Rhee, E., Liao, M., Goldstein, M., Keane, W.M., Santoro, M., Fusco, A., Rothstein, J.L., 1998. The RET/PTC3 oncogene: metastatic solid-type papillary carcinomas in murine thyroids. Cancer Res. 58, 5523-5528.

Powell, N., Jeremiah, S., Morishita, M., Dudley, E., Bethel, J., Bogdanova, T., Tronko, M., Thomas, G., 2005. Frequency of BRAF T1796A mutation in papillary thyroid carcinoma relates to age of patient at diagnosis and not to radiation exposure. J. Pathol. 205, 558-564.

Rao, A.S., Kremenevskaja, N., Resch, J., Brabant, G., 2005. Lithium stimulates proliferation in cultured thyrocytes by activating Wnt/beta-catenin signalling. Eur. J Endocrinol. 153, 929938.

Raspe, E., Laurent, E., Andry, G., Dumont, J.E., 1991. ATP, bradykinin, TRH and TSH activate the $\mathrm{Ca}(2+)$-phosphatidylinositol cascade of human thyrocytes in primary culture. Mol. Cell Endocrinol. 81, 175-183.

Raspe, E., Roger, P.P., Dumont, J.E., 1986. Carbamylcholine, TRH, PGF2 alpha and fluoride enhance free intracellular $\mathrm{Ca}++$ and $\mathrm{Ca}++$ translocation in dog thyroid cells. Biochem. Biophys. Res. Commun. 141, 569-577.

Reuse, S., Maenhaut, C., Dumont, J.E., 1990. Regulation of protooncogenes c-fos and c-myc expressions by protein tyrosine kinase, protein kinase $\mathrm{C}$, and cyclic AMP mitogenic pathways in dog primary thyrocytes: a positive and negative control by cyclic AMP on c-myc expression. Exp. Cell Res. 189, 33-40. 
Reuse, S., Pirson, I., Dumont, J.E., 1991. Differential regulation of protooncogenes c-jun and jun D expressions by protein tyrosine kinase, protein kinase $\mathrm{C}$, and cyclic-AMP mitogenic pathways in dog primary thyrocytes: TSH and cyclic-AMP induce proliferation but downregulate C-jun expression. Exp. Cell Res. 196, 210-215.

Rhoden, K.J., Unger, K., Salvatore, G., Yilmaz, Y., Vovk, V., Chiappetta, G., Qumsiyeh, M.B., Rothstein, J.L., Fusco, A., Santoro, M., Zitzelsberger, H., Tallini, G., 2006.

RET/papillary thyroid cancer rearrangement in nonneoplastic thyrocytes: follicular cells of Hashimoto's thyroiditis share low-level recombination events with a subset of papillary carcinoma. J. Clin. Endocrinol. Metab 91, 2414-2423.

Ribeiro-Neto, F., Urbani, J., Lemee, N., Lou, L., Altschuler, D.L., 2002. On the mitogenic properties of Rap1b: cAMP-induced G(1)/S entry requires activated and phosphorylated Rap1b. Proc. Natl. Acad. Sci. U. S. A. 99, 5418-5423.

Ringel, M.D., 2008. "Thyroid cancer" cell line misidentification: a time for proactive change. J Clin. Endocrinol. Metab 93, 4226-4227.

Rivas, M., Santisteban, P., 2003. TSH-activated signaling pathways in thyroid tumorigenesis. Mol. Cell Endocrinol. 213, 31-45.

Rocha, A.S., Paternot, S., Coulonval, K., Dumont, J.E., Soares, P., Roger, P.P., 2008. Cyclic AMP inhibits the proliferation of thyroid carcinoma cell lines through regulation of CDK4 phosphorylation. Mol. Biol. Cell 19, 4814-4825.

Rochefort, P., Caillou, B., Michiels, F.M., Ledent, C., Talbot, M., Schlumberger, M., Lavelle, F., Monier, R., Feunteun, J., 1996. Thyroid pathologies in transgenic mice expressing a human activated Ras gene driven by a thyroglobulin promoter. Oncogene 12, 111-118.

Roger, P., Taton, M., Van Sande, J., Dumont, J.E., 1988a. Mitogenic effects of thyrotropin and adenosine 3',5'- monophosphate in differentiated normal human thyroid cells in vitro. J. Clin. Endocrinol. Metab. 66, 1158-1165.

Roger, P.P., Baptist, M., Dumont, J.E., 1992. A mechanism generating heterogeneity in thyroid epithelial cells: suppression of the thyrotropin/cAMP-dependent mitogenic pathway after cell division induced by cAMP-independent factors. J. Cell Biol. 117, 383-393. 
Roger, P.P., Demartin, S., Dumont, J.E., 1999. Nature of the critical labile event that controls RB phosphorylation in the cyclic AMP-dependent cell cycle of thyrocytes in primary culture. Exp. Cell Res. 252, 492-498.

Roger, P.P., Dumont, J.E., 1982. Epidermal growth factor controls the proliferation and the expression of differentiation in canine thyroid cells in primary culture. FEBS Lett. 144, 209212.

Roger, P.P., Dumont, J.E., 1984. Factors controlling proliferation and differentiation of canine thyroid cells cultured in reduced serum conditions: effects of thyrotropin, cyclic AMP and growth factors. Mol. Cell Endocrinol. 36, 79-93.

Roger, P.P., Reuse, S., Maenhaut, C., Dumont, J.E., 1995. Multiple facets of the modulation of growth by cAMP. Vitam. Horm. 51, 59-191.

Roger, P.P., Reuse, S., Servais, P., Van Heuverswyn, B., Dumont, J.E., 1986. Stimulation of cell proliferation and inhibition of differentiation expression by tumor-promoting phorbol esters in dog thyroid cells in primary culture. Cancer Res. 46, 898-906.

Roger, P.P., Rickaert, F., Huez, G., Authelet, M., Hofmann, F., Dumont, J.E., 1988b. Microinjection of catalytic subunit of cyclic AMP-dependent protein kinase triggers acute morphological changes in thyroid epithelial cells. FEBS Lett. 232, 409-413.

Roger, P.P., Servais, P., Dumont, J.E., 1983. Stimulation by thyrotropin and cyclic AMP of the proliferation of quiescent canine thyroid cells cultured in a defined medium containing insulin. FEBS Lett. 157, 323-329.

Roger, P.P., Servais, P., Dumont, J.E., 1987. Induction of DNA synthesis in dog thyrocytes in primary culture: synergistic effects of thyrotropin and cyclic AMP with epidermal growth factor and insulin. J. Cell Physiol. 130, 58-67.

Roger, P.P., Van Heuverswyn, B., Lambert, C., Reuse, S., Vassart, G., Dumont, J.E., 1985. Antagonistic effects of thyrotropin and epidermal growth factor on thyroglobulin mRNA level in cultured thyroid cells. Eur. J. Biochem. 152, 239-245.

Romeo, H.E., Diaz, M.C., Ceppi, J., Zaninovich, A.A., Cardinali, D.P., 1988. Effect of inferior laryngeal nerve section on thyroid function in rats. Endocrinology 122, 2527-2532. 
Russo, D., Arturi, F., Schlumberger, M., Caillou, B., Monier, R., Filetti, S., Suarez, H.G., 1995. Activating mutations of the TSH receptor in differentiated thyroid carcinomas.

Oncogene 11, 1907-1911.

Saavedra, H.I., Knauf, J.A., Shirokawa, J.M., Wang, J., Ouyang, B., Elisei, R., Stambrook, P.J., Fagin, J.A., 2000. The RAS oncogene induces genomic instability in thyroid PCCL3 cells via the MAPK pathway. Oncogene 19, 3948-3954.

Santelli, G., de, F., V, Chiappetta, G., D'Alessio, A., Califano, D., Mineo, A., Monaco, C., Vecchio, G., 1993. Thyroid specific expression of the Ki-ras oncogene in transgenic mice. Adv. Exp. Med. Biol. 348, 59-62.

Santoro, M., Chiappetta, G., Cerrato, A., Salvatore, D., Zhang, L., Manzo, G., Picone, A., Portella, G., Santelli, G., Vecchio, G., Fusco, A., 1996. Development of thyroid papillary carcinomas secondary to tissue-specific expression of the RET/PTC1 oncogene in transgenic mice. Oncogene 12, 1821-1826.

Santoro, M., Dathan, N.A., Berlingieri, M.T., Bongarzone, I., Paulin, C., Grieco, M., Pierotti, M.A., Vecchio, G., Fusco, A., 1994. Molecular characterization of RET/PTC3; a novel rearranged version of the RETproto-oncogene in a human thyroid papillary carcinoma. Oncogene 9, 509-516.

Sartore-Bianchi, A., Martini, M., Molinari, F., Veronese, S., Nichelatti, M., Artale, S., Di Nicolantonio, F., Saletti, P., De Dosso, S., Mazzucchelli, L., Frattini, M., Siena, S., Bardelli, A., 2009. PIK3CA mutations in colorectal cancer are associated with clinical resistance to EGFR-targeted monoclonal antibodies. Cancer Res. 69, 1851-1857.

Schweppe, R.E., Klopper, J.P., Korch, C., Pugazhenthi, U., Benezra, M., Knauf, J.A., Fagin, J.A., Marlow, L.A., Copland, J.A., Smallridge, R.C., Haugen, B.R., 2008. Deoxyribonucleic acid profiling analysis of 40 human thyroid cancer cell lines reveals cross-contamination resulting in cell line redundancy and misidentification. J Clin. Endocrinol. Metab 93, 43314341.

Sherr, C.J., Roberts, J.M., 1999. CDK inhibitors: positive and negative regulators of G1-phase progression. Genes Dev. 13, 1501-1512. 
The Cancer Genome Atlas Research network, 2008. Comprehensive genomic characterization defines human glioblastoma genes and core pathways. Nature 455, 1061-1068.

Thomas, R., 1978. Logical analysis of systems comprising feedback loops. J. Theor. Biol. 73, 631-656.

Tominaga, T., Dela Cruz, J., Burrow, G.N., Meinkoth, J.L., 1994. Divergent patterns of immediate early gene expression in response to thyroid-stimulating hormone and insulin-like growth factor I in Wistar rat thyrocytes. Endocrinology 135, 1212-1219.

Tonacchera, M., Vitti, P., Agretti, P., Ceccarini, G., Perri, A., Cavaliere, R., Mazzi, B., Naccarato, A.G., Viacava, P., Miccoli, P., Pinchera, A., Chiovato, L., 1999. Functioning and nonfunctioning thyroid adenomas involve different molecular pathogenetic mechanisms. J. Clin. Endocrinol. Metab 84, 4155-4158.

Trovato, M., Villari, D., Bartolone, L., Spinella, S., Simone, A., Violi, M.A., Trimarchi, F., Batolo, D., Benvenga, S., 1998. Expression of the hepatocyte growth factor and c-met in normal thyroid, non-neoplastic, and neoplastic nodules. Thyroid. 8, 125-131.

Trovisco, V., Vieira, d.C., I, Soares, P., Maximo, V., Silva, P., Magalhaes, J., Abrosimov, A., Guiu, X.M., Sobrinho-Simoes, M., 2004. BRAF mutations are associated with some histological types of papillary thyroid carcinoma. J. Pathol. 202, 247-251.

Tsygankova, O.M., Kupperman, E., Wen, W., Meinkoth, J.L., 2000. Cyclic AMP activates Ras. Oncogene 19, 3609-3615.

Tsygankova, O.M., Saavedra, A., Rebhun, J.F., Quilliam, L.A., Meinkoth, J.L., 2001. Coordinated regulation of Rap 1 and thyroid differentiation by cyclic AMP and protein kinase A. Mol. Cell Biol. 21, 1921-1929.

Unger, K., Malisch, E., Thomas, G., Braselmann, H., Walch, A., Jackl, G., Lewis, P., Lengfelder, E., Bogdanova, T., Wienberg, J., Zitzelsberger, H., 2008. Array CGH demonstrates characteristic aberration signatures in human papillary thyroid carcinomas governed by RET/PTC. Oncogene 27, 4592-4602.

Unger, K., Zitzelsberger, H., Salvatore, G., Santoro, M., Bogdanova, T., Braselmann, H., Kastner, P., Zurnadzhy, L., Tronko, N., Hutzler, P., Thomas, G., 2004. Heterogeneity in the 
distribution of RET/PTC rearrangements within individual post-Chernobyl papillary thyroid carcinomas. J. Clin. Endocrinol. Metab 89, 4272-4279.

Uyttersprot, N., Costagliola, S., Dumont, J.E., Miot, F., 1999. Requirement for cAMPresponse element (CRE) binding protein/CRE modulator transcription factors in thyrotropininduced proliferation of dog thyroid cells in primary culture. Eur. J. Biochem. 259, 370-378.

Van Keymeulen, A., Bartek, J., Dumont, J.E., Roger, P.P., 1999. Cyclin D3 accumulation and activity integrate and rank the comitogenic pathways of thyrotropin and insulin in thyrocytes in primary culture. Oncogene 18, 7351-7359.

Van Keymeulen, A., Deleu, S., Bartek, J., Dumont, J.E., Roger, P.P., 2001. Respective roles of carbamylcholine and cyclic AMP in their synergistic regulation of cell cycle in thyroid primary cultures. Endocrinology 142, 1251-1259.

Van Keymeulen, A., Dumont, J.E., Roger, P.P., 2000a. TSH induces insulin receptors that mediate insulin co-stimulation of growth in normal human thyroid cells. Biochem. Biophys. Res. Commun. 279, 202-207.

Van Keymeulen, A., Roger, P.P., Dumont, J.E., Dremier, S., 2000b. TSH and cAMP do not signal mitogenesis through Ras activation. Biochem. Biophys. Res. Commun. 273, 154-158.

Van Sande, J., Dequanter, D., Lothaire, P., Massart, C., Dumont, J.E., Erneux, C., 2006. Thyrotropin stimulates the generation of inositol 1,4,5-trisphosphate in human thyroid cells. J Clin. Endocrinol. Metab 91, 1099-1107.

Van Sande, J., Lefort, A., Beebe, S., Roger, P., Perret, J., Corbin, J., Dumont, J.E., 1989. Pairs of cyclic AMP analogs, that are specifically synergistic for type I and type II cAMPdependent protein kinases, mimic thyrotropin effects on the function, differentiation expression and mitogenesis of dog thyroid cells. Eur. J. Biochem. 183, 699-708.

Van Sande, J., Parma, J., Tonacchera, M., Swillens, S., Dumont, J., Vassart, G., 1995. Somatic and germline mutations of the TSH receptor gene in thyroid diseases. J. Clin. Endocrinol. Metab 80, 2577-2585.

van Staveren, W.C., Solis, D.W., Delys, L., Duprez, L., Andry, G., Franc, B., Thomas, G., Libert, F., Dumont, J.E., Detours, V., Maenhaut, C., 2007. Human thyroid tumor cell lines 
derived from different tumor types present a common dedifferentiated phenotype. Cancer Res. 67, 8113-8120.

van Staveren, W.C., Solis, D.Y., Hebrant, A., Detours, V., Dumont, J.E., Maenhaut, C., 2009. Human cancer cell lines: Experimental models for cancer cells in situ? For cancer stem cells? Biochim. Biophys. Acta 1795, 92-103.

van Staveren, W.C.G., Weiss Solis, D., Delys, L., Venet, D., Cappello, M., Andry, G., Dumont, J.E., Libert, F., Detours, V., Maenhaut, C., 2006. Gene expression in human thyrocytes and autonomous adenomas reveals suppression of negative feedbacks in tumorigenesis. Proc. Natl. Acad. Sci. U. S. A. 103, 413-418.

Vandeput, F., Perpete, S., Coulonval, K., Lamy, F., Dumont, J.E., 2003. Role of the different mitogen-activated protein kinase subfamilies in the stimulation of dog and human thyroid epithelial cell proliferation by cyclic adenosine 5'-monophosphate and growth factors. Endocrinology 144, 1341-1349.

Vanvooren, V., Uchino, S., Duprez, L., Costa, M.J., Vandekerckhove, J., Parma, J., Vassart, G., Dumont, J.E., Van Sande, J., Noguchi, S., 2002. Oncogenic mutations in the thyrotropin receptor of autonomously functioning thyroid nodules in the Japanese population. Eur. J. Endocrinol. 147, 287-291.

Vella, V., Pandini, G., Sciacca, L., Mineo, R., Vigneri, R., Pezzino, V., Belfiore, A., 2002. A novel autocrine loop involving IGF-II and the insulin receptor isoform-A stimulates growth of thyroid cancer. J Clin. Endocrinol. Metab. 87, 245-254.

Vitagliano, D., Carlomagno, F., Motti, M.L., Viglietto, G., Nikiforov, Y.E., Nikiforova, M.N., Hershman, J.M., Ryan, A.J., Fusco, A., Melillo, R.M., Santoro, M., 2004. Regulation of p27Kip1 protein levels contributes to mitogenic effects of the RET/PTC kinase in thyroid carcinoma cells. Cancer Res. 64, 3823-3829.

Vogt, P.K., Kang, S., Elsliger, M.A., Gymnopoulos, M., 2007. Cancer-specific mutations in phosphatidylinositol 3-kinase. Trends Biochem. Sci. 32, 342-349.

Vuchak, L.A., Tsygankova, O.M., Prendergast, G.V., Meinkoth, J.L., 2009. Protein kinase A and B-Raf mediate extracellular signal-regulated kinase activation by thyrotropin. Mol. Pharmacol. 76, 1123-1129. 
Wang, J., Knauf, J.A., Basu, S., Puxeddu, E., Kuroda, H., Santoro, M., Fusco, A., Fagin, J.A., 2003. Conditional expression of RET/PTC induces a weak oncogenic drive in thyroid PCCL3 cells and inhibits thyrotropin action at multiple levels. Mol. Endocrinol. 17, 1425-1436.

Wang, Y., Hou, P., Yu, H., Wang, W., Ji, M., Zhao, S., Yan, S., Sun, X., Liu, D., Shi, B., Zhu, G., Condouris, S., Xing, M., 2007. High prevalence and mutual exclusivity of genetic alterations in the phosphatidylinositol-3-kinase/akt pathway in thyroid tumors. J. Clin. Endocrinol. Metab 92, 2387-2390.

Williams, D.W., Williams, E.D., Wynford-Thomas D, 1988. Loss of dependence on IGF-1 for proliferation of human thyroid adenoma cells. Br. J. Cancer 57, 535-539.

Williams, D.W., Williams, E.D., Wynford-Thomas, D., 1989. Evidence for autocrine production of IGF-1 in human thyroid adenomas. Mol. Cell Endocrinol. 61, 139-143.

Williams, E.D., Abrosimov, A., Bogdanova, T., Demidchik, E.P., Ito, M., LiVolsi, V., Lushnikov, E., Rosai, J., Sidorov, Y., Tronko, M.D., Tsyb, A.F., Vowler, S.L., Thomas, G.A., 2004. Thyroid carcinoma after Chernobyl latent period, morphology and aggressiveness. Br. J. Cancer 90, 2219-2224.

Xing, M., Clark, D., Guan, H., Ji, M., Dackiw, A., Carson, K.A., Kim, M., Tufaro, A., Ladenson, P., Zeiger, M., Tufano, R., 2009. BRAF mutation testing of thyroid fine-needle aspiration biopsy specimens for preoperative risk stratification in papillary thyroid cancer. $\mathrm{J}$. Clin. Oncol. 27, 2977-2982.

Yeager, N., Klein-Szanto, A., Kimura, S., Di Cristofano, A., 2007. Pten loss in the mouse thyroid causes goiter and follicular adenomas: insights into thyroid function and Cowden disease pathogenesis. Cancer Res. 67, 959-966.

Zeiger, M.A., Saji, M., Gusev, Y., Westra, W.H., Takiyama, Y., Dooley, W.C., Kohn, L.D., Levine, M.A., 1997. Thyroid-specific expression of cholera toxin A1 subunit causes thyroid hyperplasia and hyperthyroidism in transgenic mice. Endocrinology 138, 3133-3140.

Zeng, Q., Chen, G.G., Vlantis, A.C., van Hasselt, C.A., 2007. Oestrogen mediates the growth of human thyroid carcinoma cells via an oestrogen receptor-ERK pathway. Cell Prolif. 40, 921-935. 
Zhu, Z., Ciampi, R., Nikiforova, M.N., Gandhi, M., Nikiforov, Y.E., 2006. Prevalence of RET/PTC rearrangements in thyroid papillary carcinomas: effects of the detection methods and genetic heterogeneity. J. Clin. Endocrinol. Metab 91, 3603-3610. 


\section{Figure legends}

Figure 1. Overall summary of cooperative interactions of comitogenic pathways of TSH and insulin/IGF-I $(A)$ and comitogenic pathways of growth factors and IGF-I $(B)$, mostly mapped from investigations using dog thyroid primary cultures. $*$ and + respectively indicate mutations and overexpressions found in human thyroid tumors. Proteins labeled in green in (B) are only found or acting in thyroid tumors. Diamond/rectangle arrowheads represent inductions/repressions; the other dashed arrows are activations (green) and inhibitions (red). insR-A, IGF-II responsive insulin receptor isoform A; insR-B, insulin receptor isoform B; CDK4AK1, unknown putative CDK4 activating kinase complex possibly different from CDK4AK2.

Most observations have been confirmed and validated using primary cultures of normal human thyrocytes. This includes (i) the lack of activation by TSH and cAMP of ERK MAP kinases; (ii) the repression by TSH of c-jun and egr1, which results in reduced expression of cyclin D1 and p21 ; (iii) the up-regulation of p27 by TSH ; (iv) the selective activation of cyclin D3-CDK4 in the TSH/cAMP-dependent mitogenesis, whereas cyclin D1CDK4-p21 complexes are induced and activated by growth factors ; (v) the partially different phosphorylation of pRb by cyclin D1 and cyclin D3 complexes ; (vi) the delayed induction by TSH of insulin receptors, which allows low physiological concentrations of insulin to act as a comitogen. On the other hand, in our hands HGF only strongly induces proliferation in dog thyroid cells but not in normal human thyrocytes. However its receptor encoded by the c-met protooncogene is expressed in human papillary carcinomas. See text for references, details and explanations.

Figure 2. Kinetics of ERK1/2 activation (upper panel), PI(3,4,5)P3 generation (middle panel), and PKB activation (bottom panel) in response to various (co)mitogenic stimuli in dog thyroid primary cultures.

Only HGF durably activates both the PI-3K-PKB and ERK pathways, thus explaining that only this factor acts as a full mitogen. By contrast TSH induces proliferation without activating PI-3K-PKB and ERK pathways but depending on the presence of insulin/IGF-I. 
Figure 3. CDK4 regulation: the example of canine thyroid primary cultures.

Two distinct mitogenic modes coexist in dog thyrocytes and are differentially associated with differentiation expression. Growth factors (GF) activate CDK4 as in other systems, mainly by inducing cyclin D1 and also p21, which stabilizes the cyclin D1-CDK4 complex in the nucleus. The differentiation-associated cell cycle activation by TSH and cAMP is adjunctive to this basic control. It utilizes cyclin D3 synthesized in response to insulin or IGF-I, and p27. cAMP activates CDK4 by promoting the assembly of the cyclin D3-CDK4 complex, its association with nuclear p27, and finally the activating Thr172phosphorylation of CDK4 within this complex by an undefined CDK4 activating kinase complex (CDK4AK1) possibly different in part from the one involved in the activation of cyclin D1-CDK4 by growth factors (CDK4AK2). Activation of CDK4 complexed to cyclin D1 or cyclin D3 in these parallel mitogenic stimulations leads to partially different sitespecificity of pRb-kinase activity (see also Fig. 4). This raises the hypothesis that other functions of $\mathrm{pRb}$ related to transcriptional regulation of differentiation could be differentially affected in the TSH/cAMP- and growth factor-activated proliferation modes. TGF $\beta$ selectively inhibits the cAMP-dependent activation of cyclin D3-CDK4, not by impairing the formation of this complex, but by preventing its binding to nuclear p27, as well as by inhibiting CDK4 phosphorylation within residual p27-bound cyclin D3-CDK4 complexes. The dog thyrocyte model illustrates the dissociation of the regulated assembly of D-type cyclin-CDK4 complexes from the accumulation of their subunits, the dissociation of the nuclear import of these complexes from their assembly, and the dissociation of the ratelimiting phosphorylation of CDK4 from the formation and nuclear accumulation of the Dtype cyclin-CDK4-p27/p21 holoenzyme.

Diamond arrowheads represent inductions ; the other dashed arrows are activations (+) or inhibitions (-). Redrawn from (Bockstaele et al., 2006a).

Figure 4. Presence and activity of D-type cyclin-CDK4 complexes in normal human thyrocytes stimulated by TSH or growth factors in the presence of high insulin concentrations. The addition of EGF and $10 \%$ serum $(\mathrm{EGF}+\mathrm{S})$ increases both the accumulation of cyclin D1 and even more the pRb-kinase activity of immunoprecipitated (IP) cyclin D1-CDK4. By contrast, TSH represses cyclin D1 but increases the activity of cyclin D3-CDK4 complexes. 
This leads to different profiles of pRb-kinase activity (arrows). Redrawn from (Paternot et al., 2006b). 


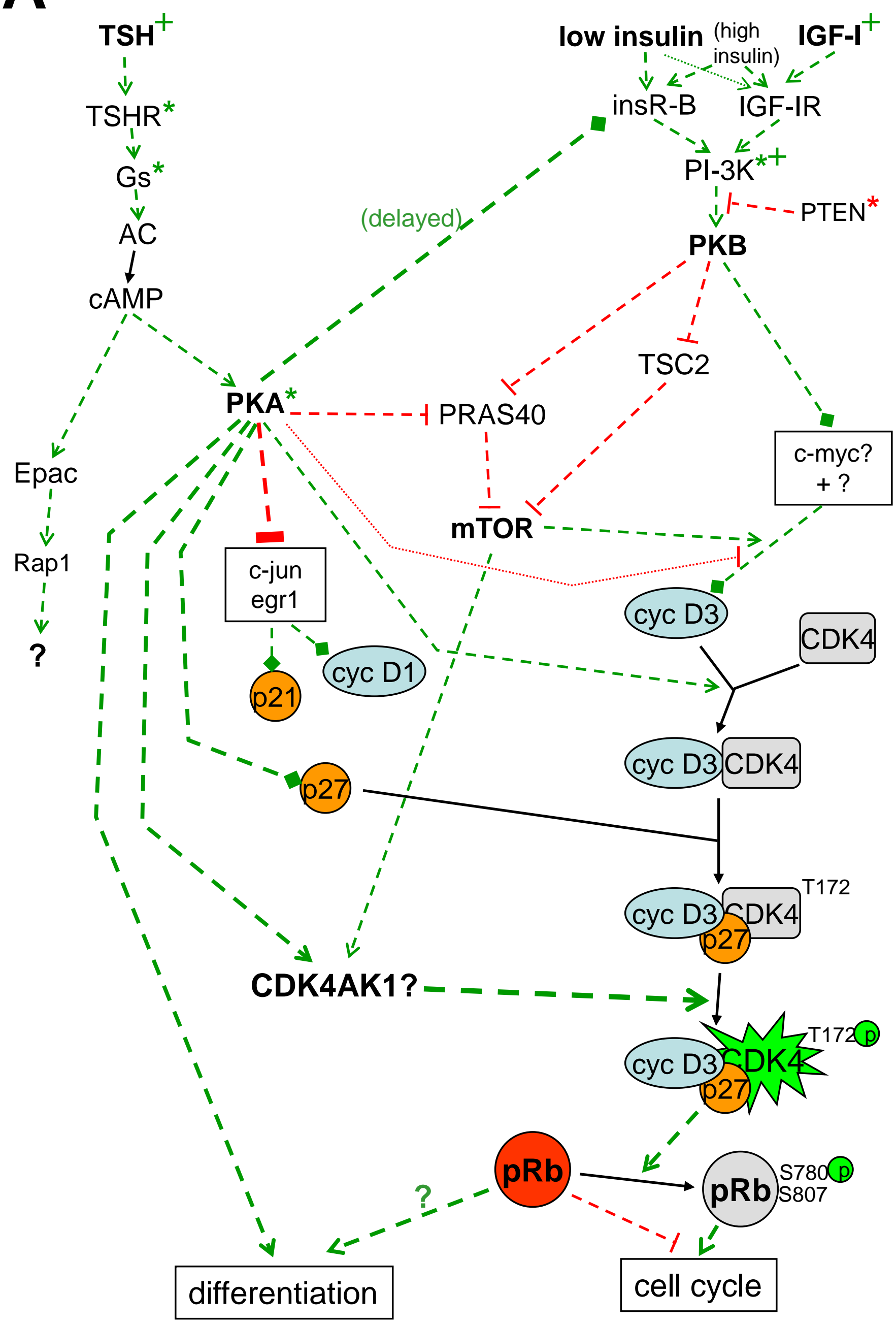




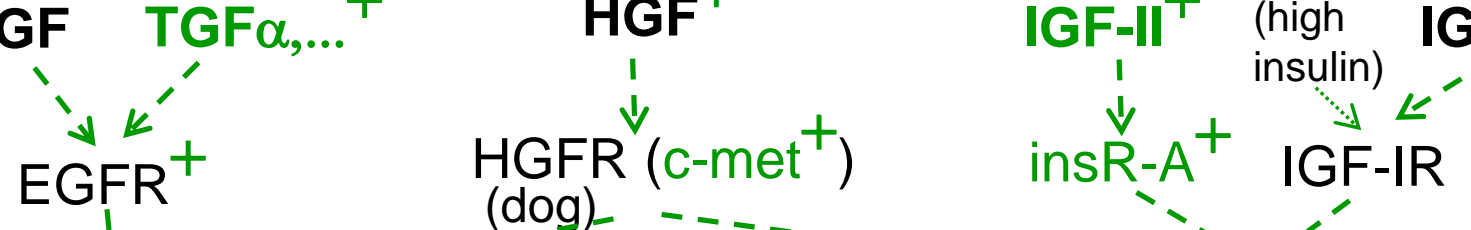

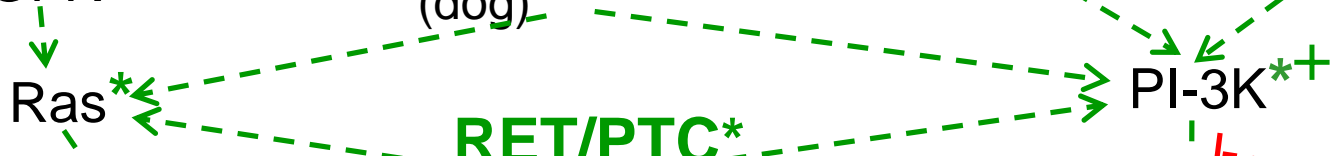

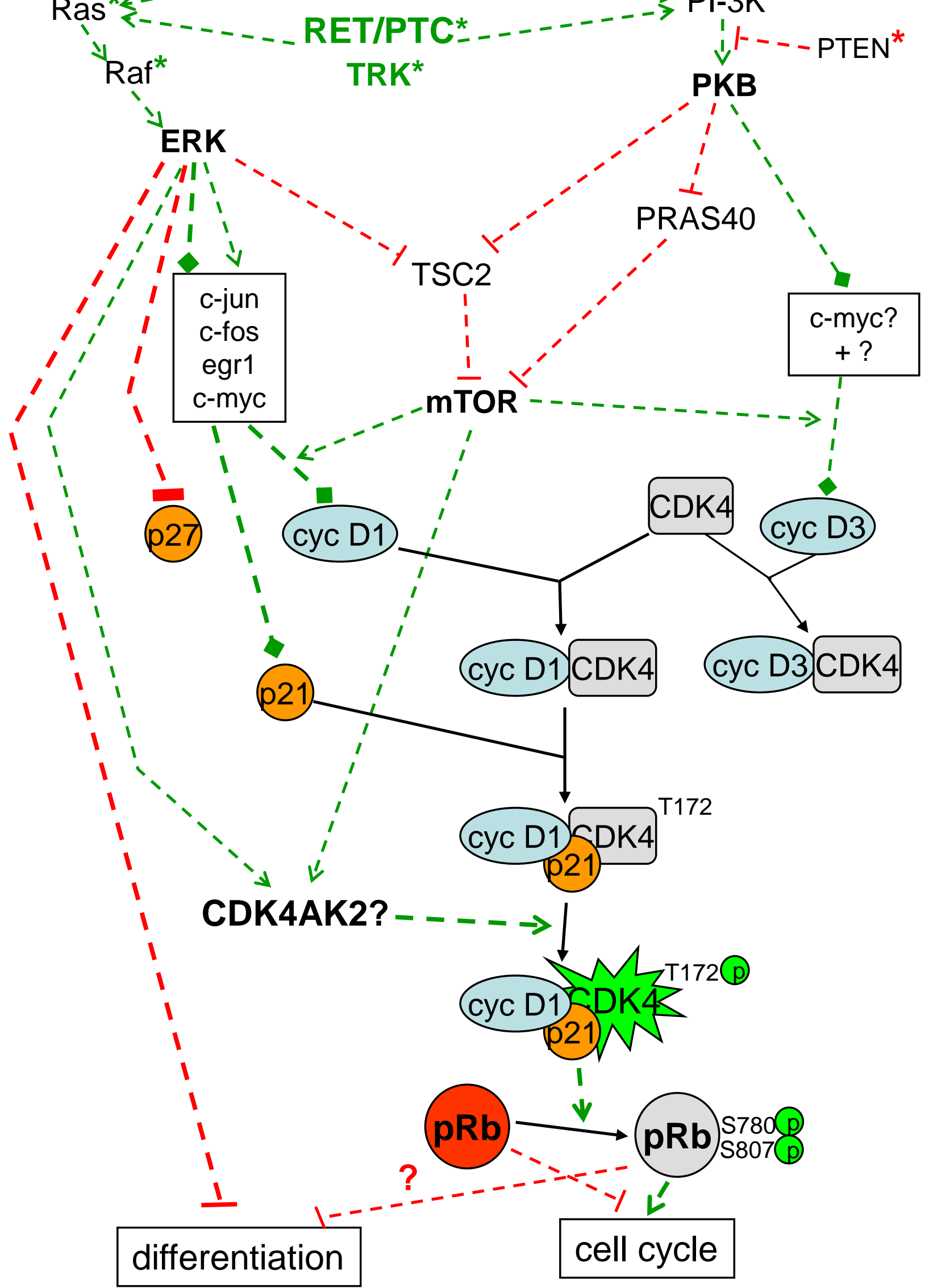



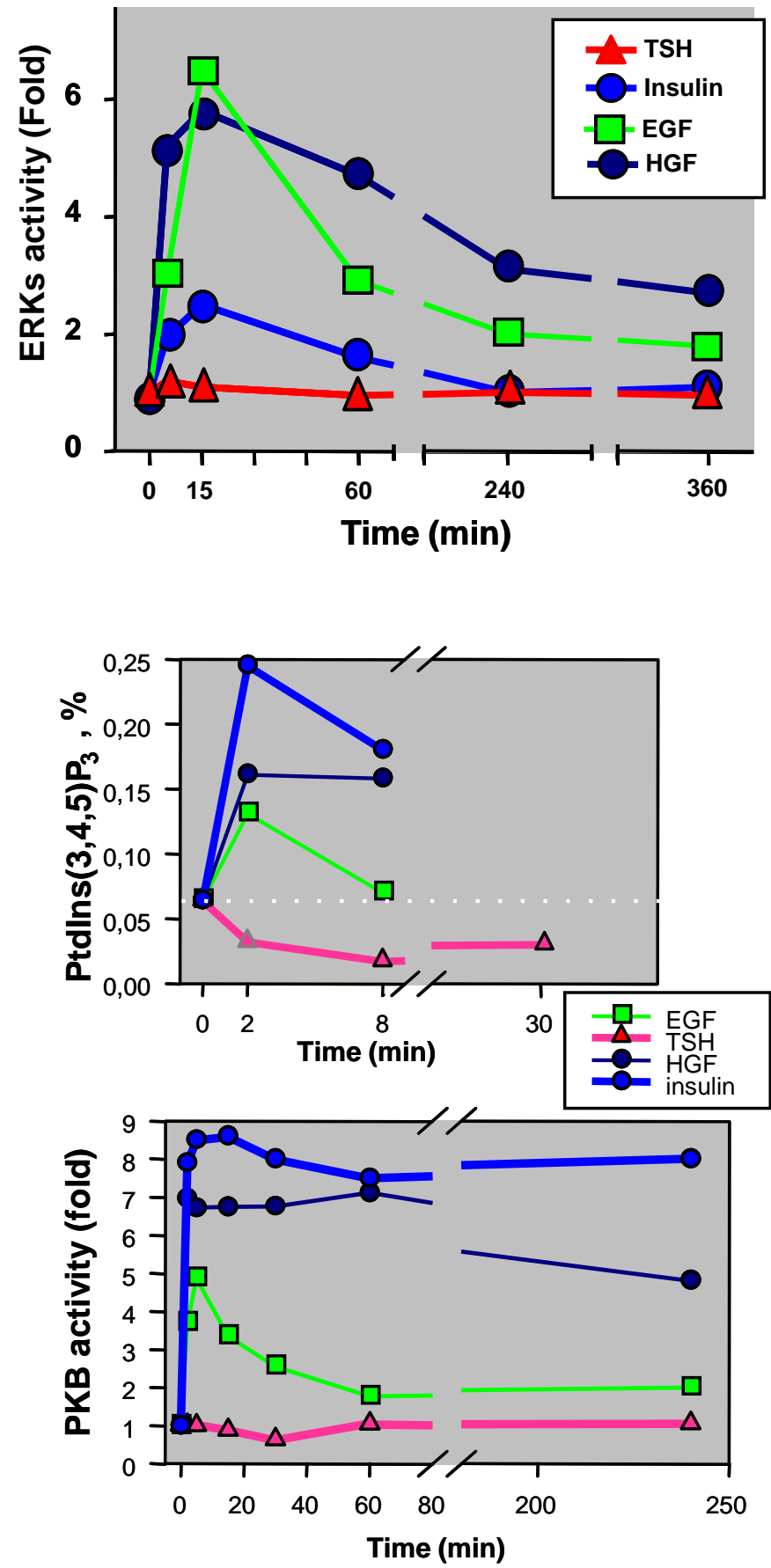


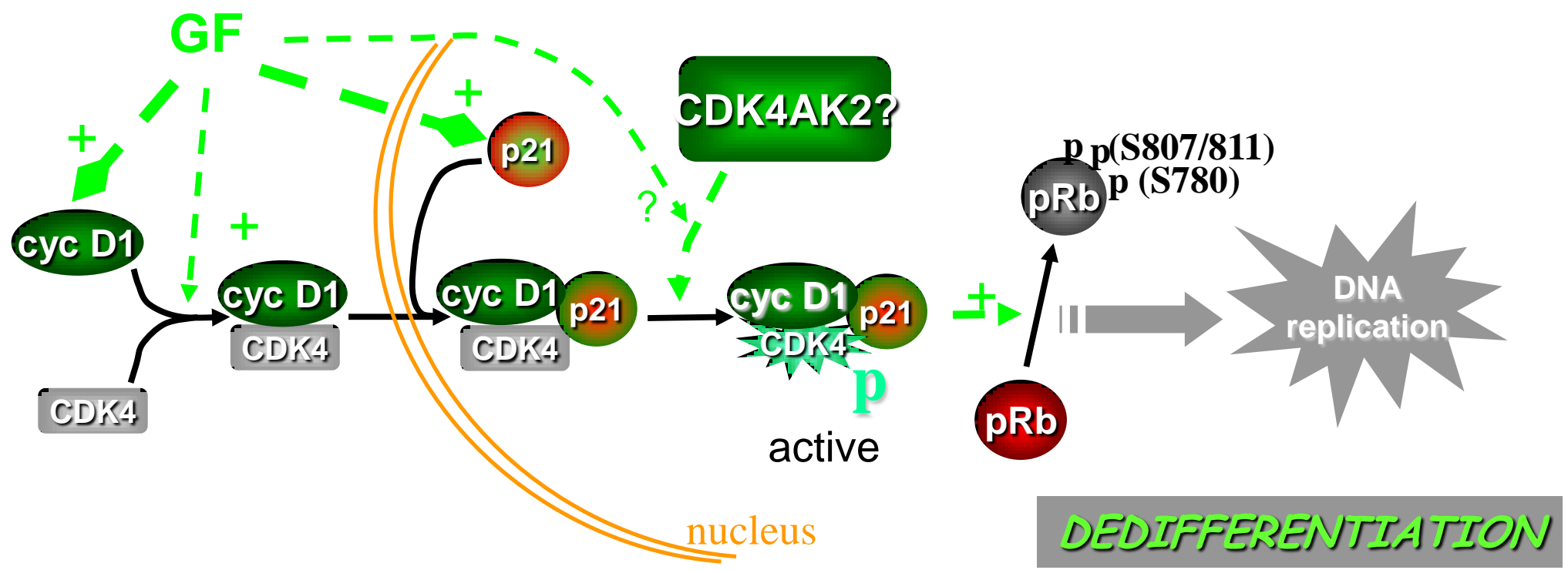

insulin/IGF
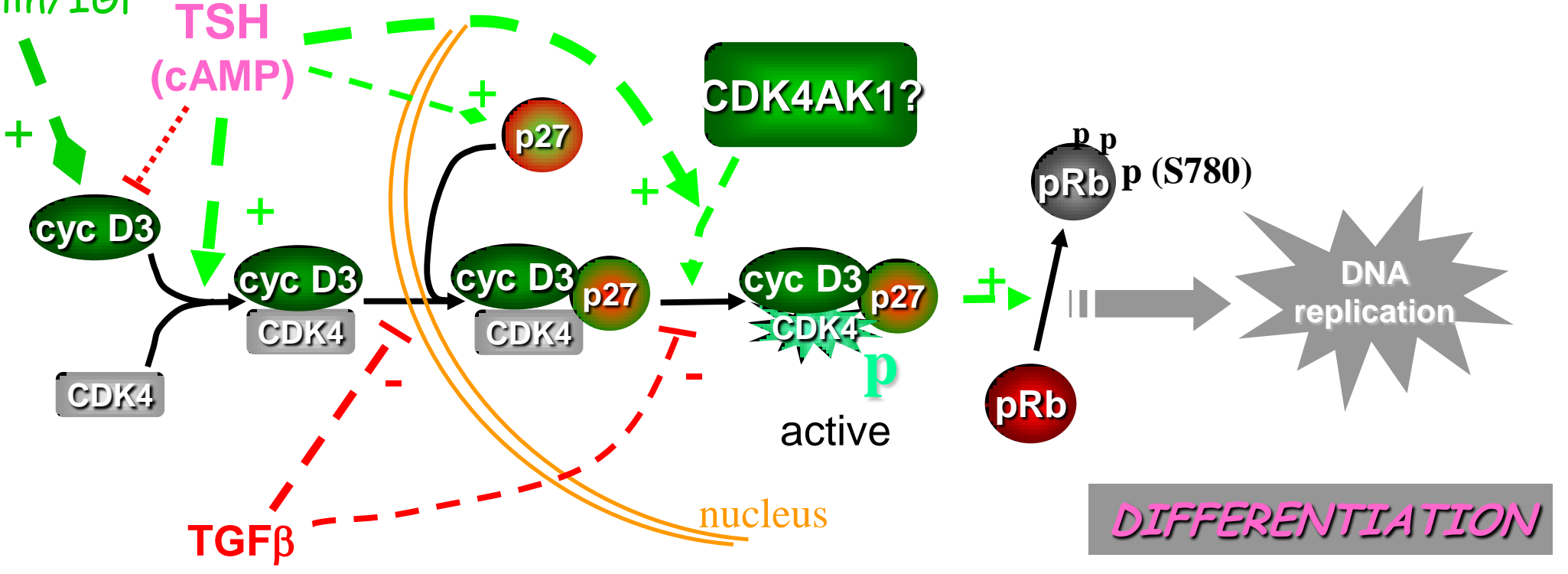


\section{Human thyrocytes in primary culture (+ insulin)}

\section{\begin{tabular}{|c|}
\hline IP \\
cyc D1/D3 \\
\hline
\end{tabular}}

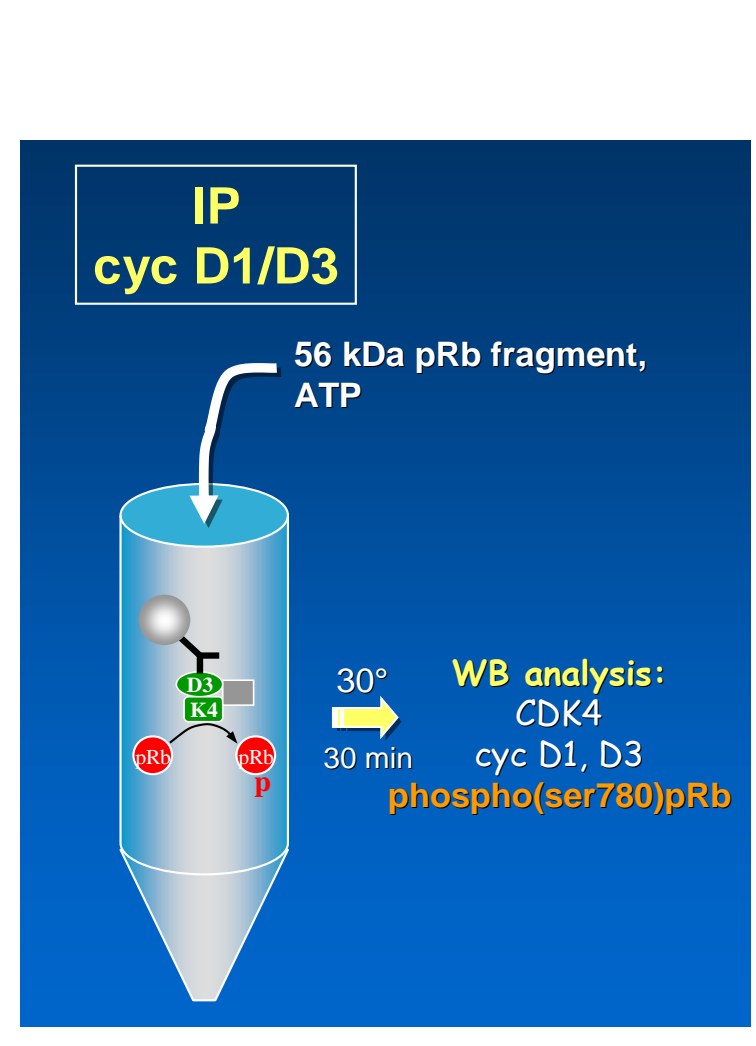

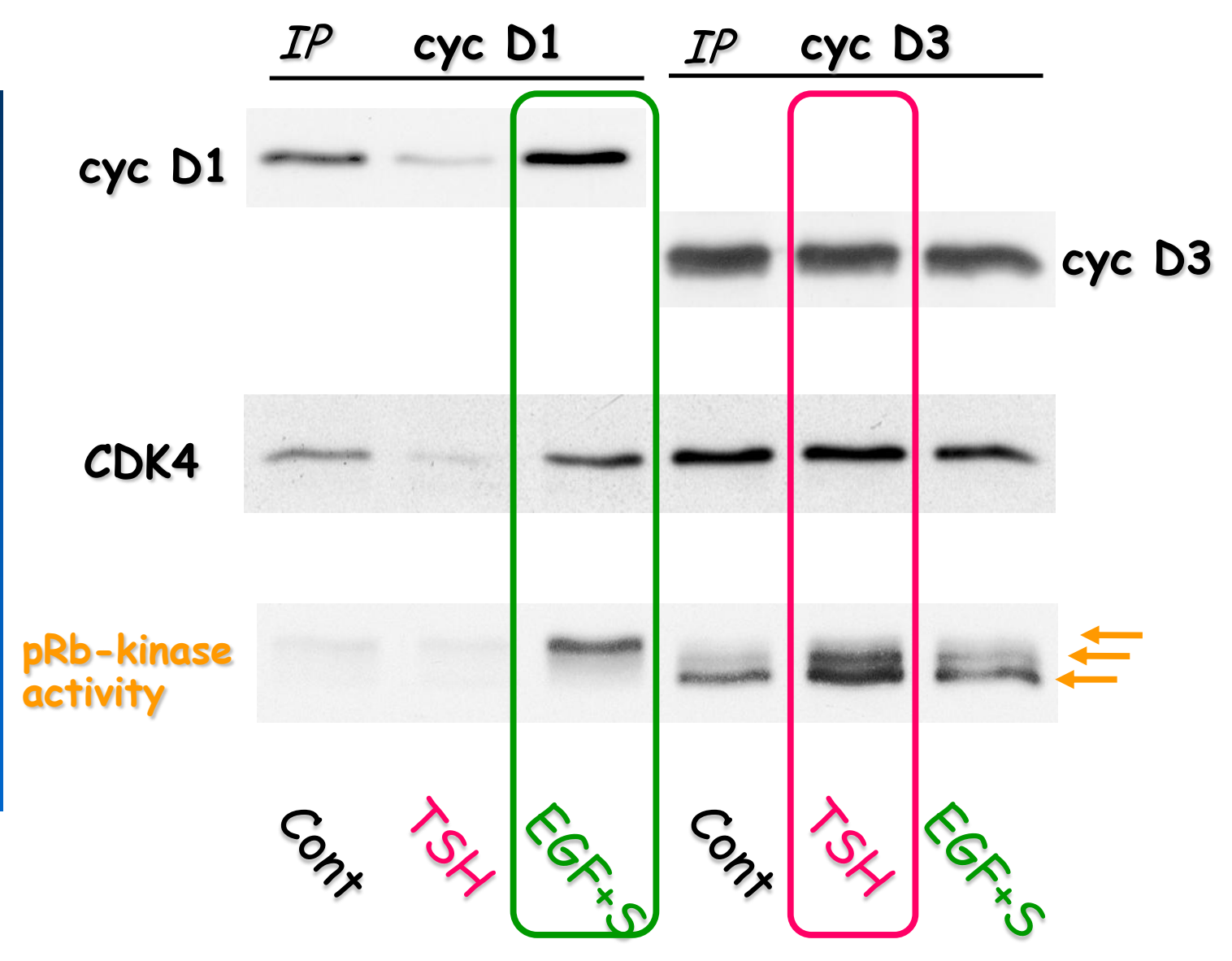

